\title{
Mechanisms of Action of Bcl-2 Family Proteins
}

\author{
Aisha Shamas-Din ${ }^{1}$, Justin Kale ${ }^{1}$, Brian Leber ${ }^{1,2}$, and David W. Andrews ${ }^{1}$ \\ ${ }^{1}$ Department of Biochemistry and Biomedical Sciences, McMaster University, Hamilton, \\ Ontario L8S4K1, Canada \\ ${ }^{2}$ Department of Medicine, McMaster University, Hamilton, Ontario L8S4K1, Canada \\ Correspondence: andrewsd@dwalab.ca
}

The Bcl-2 family of proteins controls a critical step in commitment to apoptosis by regulating permeabilization of the mitochondrial outer membrane (MOM). The family is divided into three classes: multiregion proapoptotic proteins that directly permeabilize the MOM; $\mathrm{BH} 3$ proteins that directly or indirectly activate the pore-forming class members; and the antiapoptotic proteins that inhibit this process at several steps. Different experimental approaches have led to several models, each proposed to explain the interactions between $\mathrm{Bcl}-2$ family proteins. The discovery that many of these interactions occur at or in membranes as well as in the cytoplasm, and are governed by the concentrations and relative binding affinities of the proteins, provides a new basis for rationalizing these models. Furthermore, these dynamic interactions cause conformational changes in the $\mathrm{Bcl}-2$ proteins that modulate their apoptotic function, providing additional potential modes of regulation.

\begin{abstract}
A poptosis was formally described and named A in 1972 as a unique morphological response to many different kinds of cell stress that was distinct from necrosis. However, despite the novelty and utility of the concept, little experimental work was performed during the following 20 years because no tools existed to manipulate the process. In the early 1990s, two seminal observations changed the landscape. First, as the complete developmental sequence of the nematode Caenorhabditis elegans was painstakingly elucidated at the single-cell level, it was noted that a fixed, predictable number of "intermediate" cells were destined to die, and that this process was positively and negatively regulated by specific genes. Second, a novel gene called B-cell CLL/lymphoma 2 (Bcl-2; encoded by BCL2)
\end{abstract}

that was discovered as a partner in a reciprocal chromosomal translocation in a human tumor turned out to function not as a classic oncogene by driving cell division, but rather by preventing apoptosis. When it was discovered that the mammalian BCL2 could substitute for CED-9, the $C$. elegans gene that inhibits cell death, the generality of the process was recognized, and the scientific literature exploded with now well over $10^{5}$ publications on apoptosis. However, it is ironic to note that after a further 20 years of intensive investigation, it is clear that the mechanism of action of Bcl-2 is quite distinct from Ced-9, which sequesters the activator of the caspase protease that is the ultimate effector of apoptosis. In contrast, Bcl-2 works primarily by binding to other related proteins that regulate

Editors: Eric H. Baehrecke, Douglas R. Green, Sally Kornbluth, and Guy S. Salvesen

Additional Perspectives on Cell Survival and Cell Death available at www.cshperspectives.org

Copyright (C) 2013 Cold Spring Harbor Laboratory Press; all rights reserved; doi: 10.1101/cshperspect.a008714

Cite this article as Cold Spring Harb Perspect Biol 2013;5:a008714 
A. Shamas-Din et al.

permeabilization of the mitochondrial outer membrane (MOM).

This review examines how apoptosis is regulated by the members of the (now very large) Bcl-2 family, composed of three groups related by structure and function (illustrated in Fig. 1): (1) the $\mathrm{BH} 3$ proteins that sense cellular stress and activate (either directly or indirectly); (2) the executioner proteins Bax or Bak that oligomerize in and permeabilize the MOM, thereby releasing components of the intermembrane space that activate the final, effector caspases of apoptosis; and (3) the antiapoptotic members like Bcl-2 that impede the overall process by inhibiting both the $\mathrm{BH} 3$ and the executioner proteins. To understand the consequence of the interactions among the three subgroups, several models have been proposed ("direct activation," "displacement," “embedded together," and "unified" models; illustrated in Fig. 2) that are briefly described here before a more detailed discussion of the Bcl-2 families.

\section{DIRECT ACTIVATION MODEL}

The distinctive feature of the direct activation model is that a $\mathrm{BH} 3$ protein is required to directly bind and to activate the Bcl-2 multihomology region proapoptotic proteins, Bax and Bak. The direct activation model classifies $\mathrm{BH} 3$ proteins as activators or sensitizers based on their affinities for binding to Bcl-2 multiregion proteins (see Table 1) (Letai et al. 2002). The activator $\mathrm{BH} 3$ proteins- $\mathrm{tBid}, \mathrm{Bim}$, and Puma-bind to both the proapoptotic and the antiapoptotic Bcl-2 multiregion proteins (Kim et al. 2006). The sensitizer BH3 proteins-Bad,

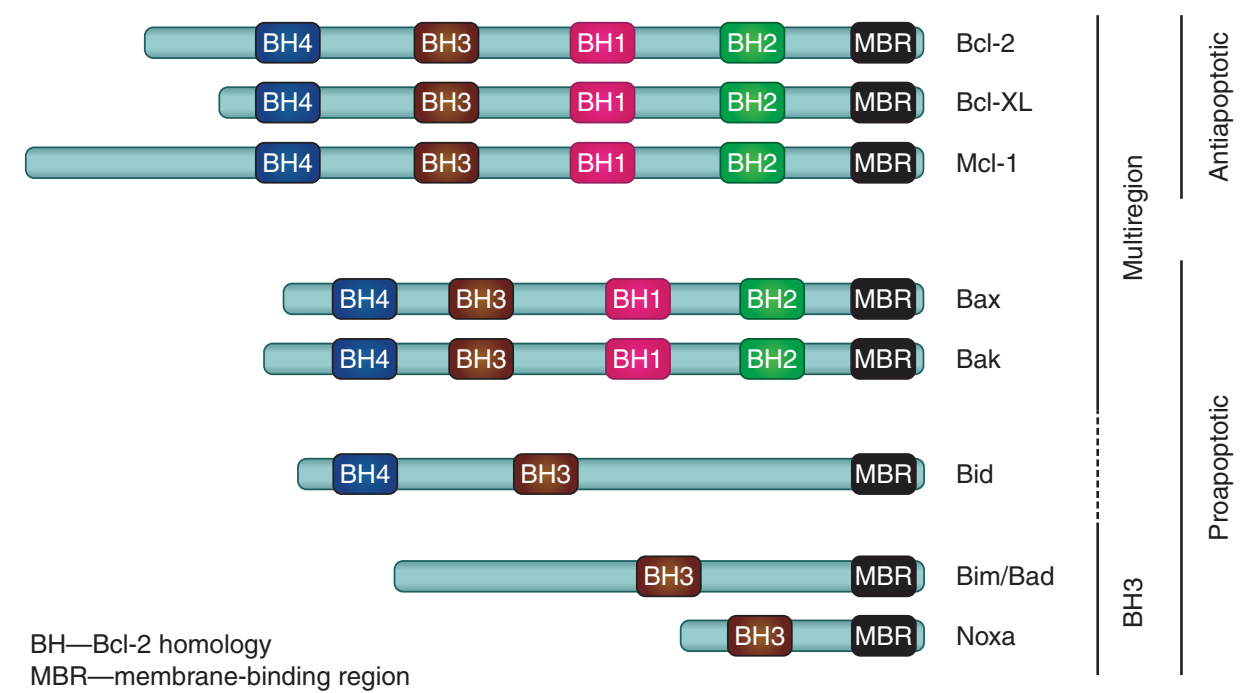

Figure 1. Schematic overview of the Bcl-2 family of proteins. The family is divided into two subgroups containing proteins that either inhibit apoptosis or promote apoptosis. The proapoptotic proteins are further subdivided functionally into those that oligomerize and permeabilize the MOM, such as Bax and Bak, or those that promote apoptosis through either activating Bax or Bak or inhibiting the antiapoptotic proteins, such as tBid, Bim, Bad, and Noxa. Proteins are included in the Bcl-2 family based on sequence homology to the founding member, Bcl-2, in one of the four Bcl-2 homology $(\mathrm{BH})$ regions. All the antiapoptotic proteins, as well as Bax, Bak, and Bid, have multiple BH regions, are evolutionarily related, and share a three-dimensional (3D) structural fold. The $\mathrm{BH} 3$ proteins contain only the $\mathrm{BH} 3$ region, are evolutionarily distant from the multiregion proteins, and are intrinsically unstructured. Most members of the Bcl-2 family proteins contain a membrane-binding region (MBR) on their carboxyl termini in the form of a tail anchor, mitochondrialtargeting sequence, or as a hydrophobic amino acid sequence that facilitates binding and localization of these proteins to the MOM or to the endoplasmic reticulum (ER) membrane. 
A Direct activation

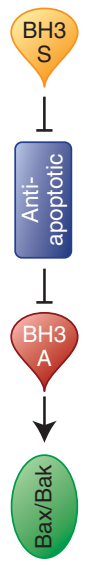

B Displacement

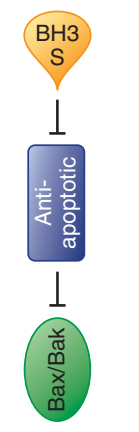

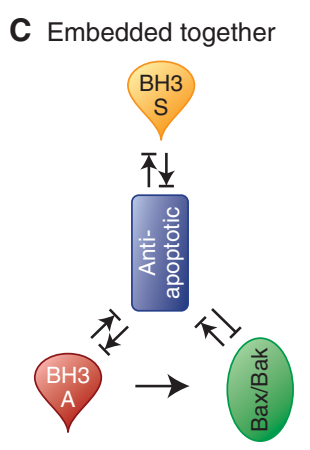

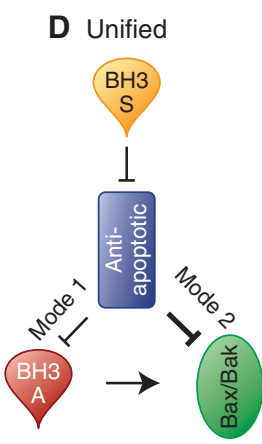

Figure 2. Schematics of the core mechanisms proposed by various models for the regulation of MOMP by Bcl-2 proteins. $(\uparrow)$ Activation; $(\perp)$ inhibition; $(\perp \uparrow)$ mutual recruitment/sequestration. Paired forward and reverse symbols indicate the model makes explicit reference to equilibria. $(A)$ The direct activation model divides the different $\mathrm{BH} 3$ proteins by qualitative differences in function. The $\mathrm{BH} 3$ proteins with high affinity for binding and activating Bax and Bak are termed as "activators," whereas those that only bind the antiapoptotic proteins are termed "sensitizers." The activator BH3 proteins directly interact with and activate Bax and Bak to promote MOMP. The antiapoptotic proteins inhibit MOMP by specifically sequestering the $\mathrm{BH} 3$ activators. The $\mathrm{BH} 3$ sensitizer proteins can compete for binding with the antiapoptotic proteins, thus releasing the $\mathrm{BH} 3$ activator proteins to avidly promote MOMP through activation and oligomerization of Bax and Bak. (B) The displacement model categorizes the $\mathrm{BH} 3$ proteins solely based on their affinities of binding for the antiapoptotic proteins (hence, does not recognize them as activators). In this model, Bax and Bak are constitutively active and oligomerize and induce MOMP unless held in check by the antiapoptotic proteins. Therefore, for a cell to undergo apoptosis, the correct combination of $\mathrm{BH} 3$ proteins must compete for binding for the different antiapoptotic proteins to liberate Bax and Bak and for MOMP to ensue. $(C)$ The embedded together model introduces an active role for the membrane and combines the major aspects of the previous models. The interactions between members of the Bcl-2 family are governed by equlibria and therefore are contingent on the relative protein concentrations as well as their binding affinities. The latter are determined by posttranslational modifications, fraction of protein bound to the membrane, and cellular physiology. At membranes, the activator $\mathrm{BH} 3$ proteins directly activate $\mathrm{Bax}$ and Bak, which then oligomerize, inducing MOMP. Both activator and sensitizer $\mathrm{BH} 3$ proteins can recruit and sequester antiapoptotic proteins in the membrane. The antiapoptotic proteins inhibit apoptosis by sequestering the $\mathrm{BH} 3$ proteins and Bax and Bak in the membrane or by preventing their binding to membranes. At different intracellular membranes, the local concentrations of specific subsets of Bcl-2 family members alter the binding of Bcl-2 proteins to the membrane and the binding equilibria between family members. As a result, Bcl-2 family proteins have distinct but overlapping functions at different cellular locations. $(D)$ The unified model builds on the embedded together model by proposing that the antiapoptotic proteins sequester the activator $\mathrm{BH} 3$ proteins (mode 1) and sequester Bax and Bak (mode 2). It differs in that in the unified model, inhibition of apoptosis through mode 1 is less efficient (smaller arrow in panel $D$ ) and therefore easier to overcome by sensitizer BH3 proteins. In addition, the unified model extends the role of Bcl-2 family proteins and the regulation of MOMP to mitochondria dynamics (not shown).

Noxa, Bik, Bmf, Hrk, and Bnip3-bind to the antiapoptotic proteins, thereby liberating activator $\mathrm{BH} 3$ proteins to promote mitochondrial outer membrane permeabilization (MOMP) (Letai et al. 2002; Kuwana et al. 2005; Certo et al. 2006). The antiapoptotic proteins bind to both the activator and the sensitizer $\mathrm{BH} 3$ proteins, but are unable to complex with Bax and Bak (Kim et al. 2006). Therefore, for a cell to evade apoptosis, antiapoptotic proteins must sequester the $\mathrm{BH} 3$ proteins to prevent Bax/Bak activation and apoptosis. 
A. Shamas-Din et al.

Table 1. Binding profiles within Bcl-2 family members

\begin{tabular}{|c|c|c|c|}
\hline \multirow{3}{*}{$\begin{array}{l}\text { Antiapoptotic } \\
\text { protein } \\
\end{array}$} & \multicolumn{3}{|c|}{ Antiapoptotic protein binds to } \\
\hline & \multirow{2}{*}{$\begin{array}{c}\text { Bax/ } \\
\text { Bak/Bid }\end{array}$} & \multicolumn{2}{|c|}{$\mathrm{BH} 3$ proteins } \\
\hline & & Activator & Sensitizer \\
\hline Bcl-2 & Bax, Bid & Bim, Puma & Bmf, Bad \\
\hline $\mathrm{Bcl}-\mathrm{XL}$ & $\begin{array}{c}\text { Bax, Bak, } \\
\text { Bid }\end{array}$ & Bim, Puma & $\begin{array}{l}\text { Bmf, Bad, } \\
\text { Bik, Hrk }\end{array}$ \\
\hline Bcl-w & $\begin{array}{c}\text { Bax, Bak, } \\
\text { Bid }\end{array}$ & Bim, Puma & $\begin{array}{l}\text { Bmf, Bad, } \\
\text { Bik, Hrk }\end{array}$ \\
\hline Mcl-1 & Bak, Bid & Bim, Puma & Noxa, Hrk \\
\hline A1 & Bak, Bid & Bim, Puma & $\begin{array}{c}\text { Noxa, Bik, } \\
\text { Hrk }\end{array}$ \\
\hline
\end{tabular}

Letai et al. (2002); Chen et al. (2005).

\section{DISPLACEMENT MODEL}

In the displacement model, $\mathrm{BH} 3$ proteins do not directly bind to Bax and Bak to cause their activation. Rather, Bax and Bak are constitutively active and therefore must be inhibited by the antiapoptotic proteins for the cell to survive. To initiate apoptosis, $\mathrm{BH} 3$ proteins displace $\mathrm{Bax}$ and Bak from the antiapoptotic proteins to promote Bax- or Bak-mediated MOMP. Because $\mathrm{BH} 3$ proteins selectively interact with a limited spectrum of antiapoptotic proteins, a combination of $\mathrm{BH} 3$ proteins is required to induce apoptosis in cells expressing multiple antiapoptotic Bcl-2 family members (see Table 1) (Chen et al. 2005). In support for this model, heterodimers of Bak with Mcl-1 and Bcl-XL are present in dividing cells, and overexpression of Noxa displaces Bak-Mcl-1 heterodimers, releasing Bak and forming Noxa-Mcl-1 complexes. In these cells, a combination of Bad and Noxa is required to neutralize the effects of both $\mathrm{Bcl}-\mathrm{XL}$ and $\mathrm{Mcl}-1$ to finally induce apoptosis (Willis et al. 2005).

\section{EMBEDDED TOGETHER MODEL}

The embedded together model incorporates the role of the membrane as the "locus of action" for most Bcl-2 family proteins because MOMP does not occur until Bax and Bak achieve their final active conformation in the membrane. The interactions with membranes result in distinct changes in conformations of the Bcl-2 family proteins that govern their affinity for the relative local concentrations of the binding partners (Leber et al. 2007, 2010; Garcia-Saez et al. 2009). For example, the cytoplasmic multiregion proteins Bax and Bcl-XL undergo large but reversible conformational changes after interacting with MOM (Edlich et al. 2011), which increase the affinity for binding to a $\mathrm{BH} 3$ protein, causing a further conformational change and allowing insertion in the membrane.

In this model, sensitizer $\mathrm{BH} 3$ proteins bind only to antiapoptotic proteins. However, the consequences of this interaction incorporate the features of both the displacement and direct activation models, because the sensitizer $\mathrm{BH} 3$ proteins neutralize the dual function of the antiapoptotic proteins by displacing both the activator $\mathrm{BH} 3$ proteins and Bax or Bak from the membrane-embedded conformers of the antiapoptotic proteins (Billen et al. 2008; Lovell et al. 2008). Because it is the activated forms of Bax and Bak that are bound to the membrane-embedded antiapoptotic proteins, sensitizer proteins release Bax and Bak conformers competent to oligomerize and permeabilize membranes.

Another distinguishing feature of this model is the dual role assigned to activator $\mathrm{BH} 3$ proteins, which directly activate proapoptotic proteins and also bind to antiapoptotic proteins. When activator $\mathrm{BH} 3$ proteins interact with Bax and Bak, they promote insertion into the membrane, whereupon Bax and Bak oligomerize and permeabilize cellular membranes. Similarly, interaction of activator $\mathrm{BH} 3$ proteins with antiapoptotic proteins promotes their insertion into membranes. However, in this case, the $\mathrm{BH} 3$ protein functions like a sensitizer, because the bound antiapoptotic protein is unable to bind Bax or Bak. However, sequestration goes both ways, and by binding the $\mathrm{BH} 3$ protein, the antiapoptotic protein inhibits it at the membrane. Moreover, because the interaction of the activator $\mathrm{BH} 3$ proteins with both the proapoptotic and the antiapoptotic Bcl-2 family proteins is reversible, it is therefore possible for a single $\mathrm{BH} 3$ protein to interact with both proapoptotic and antiapoptotic proteins (depend- 
ing on their relative expression levels), thereby changing their conformation at the membranes. Recently, many of the interactions proposed by this model have been measured directly in living cells (Aranovich et al. 2012).

\section{UNIFIED MODEL}

The unified model of Bcl-2 family function builds on the embedded together model (Llambi et al. 2011). This model distinguishes the known interactions of antiapoptotic $\mathrm{Bcl}-2$ proteins to sequester the activator $\mathrm{BH} 3$ proteins as mode 1 , and to sequester the active forms of Bax and Bak as mode 2 (Fig. 2D). Although in cells both modes of inhibition take place simultaneously, in the unified model, inhibition of apoptosis through mode 1 is less efficient and is easier to overcome by $\mathrm{BH} 3$ sensitizers to promote MOMP than inhibition through mode 2. Importantly, the unified model also incorporates the functions of Bax and Bak in mitochondrial fission and fusion and postulates that only mode 2 repression affects this process. This model is therefore the first to explicitly link modes of MOMP regulation and mitochondrial dynamics.

The dual function assigned to antiapoptotic proteins is thus shared by both embedded together and unified models. However, in the former, the interplay between members of the Bcl-2 family are determined by competing equilibria; therefore, the abundance of proteins and specific conditions of cell physiology including posttranslational modifications will determine the prevailing interactions. As a result, the embedded together model differs from the unified model in that it predicts that either mode 1 or mode 2 can be dominant depending on circumstances such as the particular form of stress and cell type. Further work to test the different predictions of the models with full-length, wildtype proteins in different cells is required to resolve these issues.

\section{THE MODELS: WHO BINDS TO WHOM?}

One aspect of many of the models that is potentially confusing is that if an activator $\mathrm{BH} 3$ pro- tein binds to an antiapoptotic family member, which is being inhibited? Whether antiapoptotic proteins sequester the $\mathrm{BH} 3$ proteins or the $\mathrm{BH} 3$ proteins sequester the antiapoptotic proteins becomes a semantic argument. A more productive way of characterizing the interaction is as a mutual sequestration that prevents their respective activation or inhibition effects on Bax and Bak. Therefore, whether MOMP ensues is determined by the relative concentrations and affinities of the proapoptotic and antiapoptotic proteins at the membrane. This recasting of the players is reminiscent of the original rheostat model proposed by the Korsmeyer group (Oltvai et al. 1993); however, it extends that model in ways not originally envisioned. For example, the rheostat model did not anticipate autoactivation. If there is sufficient cytosolic antiapoptotic Bcl-XL, then those Bcl$\mathrm{XL}$ molecules recruited to the membrane by a $\mathrm{BH} 3$ protein can recruit additional molecules of Bcl-XL to the membrane through "autoactivation," a process also observed for Bax. Because $\mathrm{BH} 3$ protein binding is reversible, autoactivation ensures recruitment of sufficient Bcl-XL to provide efficient inhibition of the $\mathrm{BH} 3$ protein.

Another recently recognized aspect that determines the nature and fate of the binding interactions is composition of different membrane organelles. As mentioned above, the unified model provides a mechanistic link between MOMP regulation and mitochondrial fission and fusion. The importance of membranes in modifying conformations and binding partners as proposed by the embedded together model accounts for the overlapping but distinct function of the Bcl-2 family at the mitochondria and endoplasmic reticulum (ER). It also explains how other membrane sites such as the Golgi can act as a reservoir for potentially activated Bax (Dumitru et al. 2012). Therefore, the roles of Bcl-2 family proteins in cell fate decisions and other processes such as mitochondrial fusion and autophagy appear to be primarily governed by the relative concentrations and affinities of the different binding partners available in that specific subcellular membrane. 
A. Shamas-Din et al.

\section{MULTIDOMAIN PROAPOPTOTIC MEMBERS}

Bax (Bcl-2-associated X protein) was identified by coimmunoprecipitation with Bcl-2 (Oltvai et al. 1993). Unlike Bcl-2, overexpression of Bax promoted cell death, and the opposing functions suggested a rheostat model, whereby the relative concentrations of proapoptotic and antiapoptotic Bcl-2 family members determine cell fate. The discovery of Bcl-XL indicated that antiapoptotic function could be mediated by more than Bcl-2; shortly thereafter Bak (Bcl2 antagonist/killer) was cloned and recognized as the second proapoptotic protein functioning similarly to Bax despite being more homologous to Bcl-2 than Bax (Chittenden et al. 1995; Farrow et al. 1995; Kiefer et al. 1995). Cells in which the gene encoding either Bax or Bak was knocked out were still susceptible to apoptosis. However, $\mathrm{Bax}^{-/-} / \mathrm{Bak}^{-/-}$doubleknockout cells were resistant to almost all death stimuli (Wei et al. 2001). These seminal studies placed Bax and Bak in the same prodeath pathway and indicated significant functional redundancy. Furthermore, the demonstration that they are jointly necessary for almost all types of apoptotic cell death (except for death receptor pathways, where effector caspases are directly activated by initiator caspases) provides the mechanism for integration of proapoptotic and antiapoptotic signals via the common mechanism of Bax- and Bak-mediated membrane permeabilization.

Both Bax and Bak mediate prodeath function at the MOM, where they oligomerize and permeabilize the MOM, resulting in the release of intermembrane space (IMS) proteins such as cytochrome $c$, OMI/HTRA2, SMAC/DIABLO, and endonuclease G (Kuwana and Newmeyer 2003). The solution structures of Bax and Bak reveal that both proteins are composed of nine $\alpha$ helices with a large hydrophobic pocket composed of helices 2-4 (Suzuki et al. 2000; Moldoveanu et al. 2006). Both Bax and Bak contain a carboxy-terminal transmembrane region, $\alpha$ helix 9 , which targets the proteins to the MOM (see Table 2).

The differences between Bax and Bak are illuminating with respect to the common mech- anism. Whereas Bax has a high affinity for the antiapoptotic proteins, Bcl-2 and Bcl-XL, Bak has a high affinity for the antiapoptotic proteins, Mcl-1 and Bcl-XL (Willis et al. 2005; Llambi et al. 2011). Another difference is that Bak is found constitutively bound to the MOM, whereas Bax is primarily cytosolic but migrates to the MOM after apoptotic stimuli (Hsu et al. 1997; Wolter et al. 1997; Griffiths et al. 1999). The difference in localization of Bax and Bak in nonstressed cells is a result of the position of helix 9. NMR studies indicate that in the initial step of activation, helix 9 of Bax is bound to the hydrophobic pocket in "cis," preventing helix 9 from inserting into the MOM (Suzuki et al. 2000). Disruption of the interaction of helix 9 with the hydrophobic pocket causes constitutive Bax targeting to the mitochondria, thus recapitulating the intracellular location of Bak (Nechushtan et al. 1999; Brock et al. 2010). Conversely, tethering helix 9 to the hydrophobic core of Bax abrogates Bax targeting to MOM and membrane permeabilization (Gavathiotis et al. 2010). Other portions of the protein involved in membrane binding (and MOMP) once helix 9 is displaced are described below. In contrast, it is presumed that helix 9 of Bak is positioned differently, because Bak bypasses the initial step of Bax activation and targets constitutively to mitochondrial membranes (Setoguchi et al. 2006).

\section{Bax/Bak-Mediated MOMP}

It was proposed that activated Bax would assemble a complex of proteins termed the permeability transition pore (PTP) to create an opening spanning through both membranes of the mitochondria, ultimately causing the MOM to rupture because of mitochondrial matrix swelling (Schwarz et al. 2007). The PTP is composed of the voltage-dependant anion channel (VDAC1) located within the MOM, adenine nucleotide translocase (ANT) located within the mitochondrial inner membrane (MIM), and cyclophilin D located within the mitochondrial matrix (Brenner and Grimm 2006). Opening of the pore would ensue after activated Bax bound to VDAC1, causing a conformational 
Mechanisms of Action of Bcl-2 Family Members

Table 2. Localization, targeting mechanism, and nonapoptotic function of Bcl-2 family proteins

\begin{tabular}{|c|c|c|c|}
\hline $\begin{array}{l}\mathrm{Bcl}-2 \\
\text { protein }\end{array}$ & $\begin{array}{l}\text { Targeting mechanism } \\
\text { and location }\end{array}$ & Nonapoptotic function & References \\
\hline Bax & $\begin{array}{l}\text { Tail anchor } \\
\text { Cystolic binds to MOM and ER } \\
\text { membrane upon activation }\end{array}$ & $\begin{array}{l}\text { Promotes mitochondria fusion } \\
\text { in healthy cells and } \\
\text { mitochondria fission in dying } \\
\text { cells }\end{array}$ & $\begin{array}{l}\text { Annis et al. 2005; Karbowski } \\
\text { et al. 2006; Montessuit et al. } \\
\text { 2010; Hoppins et al. } 2011\end{array}$ \\
\hline Bak & $\begin{array}{l}\text { Tail anchor } \\
\text { Constitutively bound to MOM } \\
\text { and ER membrane }\end{array}$ & $\begin{array}{l}\text { Promotes mitochondria fusion } \\
\text { in healthy cells, and } \\
\text { mitochondria fission in dying } \\
\text { cells }\end{array}$ & $\begin{array}{l}\text { Griffiths et al. 1999; } \\
\text { Karbowski et al. 2006; } \\
\text { Brooks et al. } 2007\end{array}$ \\
\hline Bid & $\begin{array}{l}\text { Carboxy-terminal anchor? } \\
\text { Helices } 6 \text { and } 7 \text { required for } \\
\text { membrane binding } \\
\text { Cytosolic and nuclear in healthy } \\
\text { cells } \\
\text { Localizes to MOM and ER upon } \\
\text { cleavage by caspase- } 8 \text { on the } \\
\text { onset of apoptosis }\end{array}$ & $\begin{array}{l}\text { Preserves genomic integrity and } \\
\text { mediates intra-S-phase check } \\
\text { point } \\
\text { Interacts with and modulates } \\
\text { NOD1 inflammatory } \\
\text { response }\end{array}$ & $\begin{array}{l}\text { Li et al. 1998; Luo et al. 1998; } \\
\text { Hu et al. 2003; Kamer et al. } \\
\text { 2005; Zinkel et al. 2005; } \\
\text { Yeretssian et al. } 2011\end{array}$ \\
\hline Bcl-2 & $\begin{array}{l}\text { Tail anchor } \\
\text { Constitutively bound to MOM } \\
\text { and/or ER membrane }\end{array}$ & $\begin{array}{l}\text { Bcl-2 binds to the IP3 receptor } \\
\text { at the ER, and inhibits the } \\
\text { initiation phase of calcium- } \\
\text { mediated apoptosis }\end{array}$ & $\begin{array}{l}\text { Nguyen et al. 1993; Janiaket al. } \\
\text { 1994; Hinds et al. 2003; } \\
\text { Wilson-Annan et al. 2003; } \\
\text { Chou et al. 2006; Dlugosz } \\
\text { et al. 2006; Rong et al. } 2009\end{array}$ \\
\hline Bcl-XL & $\begin{array}{l}\text { Tail anchor } \\
\text { Binds to MOM and ER } \\
\text { membrane upon activation }\end{array}$ & $\begin{array}{l}\text { Bcl-XL links apoptosis and } \\
\text { metabolism via acetyl-CoA } \\
\text { levels }\end{array}$ & $\begin{array}{l}\text { Jeong et al. 2004; Brien et al. } \\
\text { 2009; Yi et al. } 2011\end{array}$ \\
\hline Mcl-1 & $\begin{array}{l}\text { Tail anchor } \\
\text { Binds to MOM upon activation }\end{array}$ & $\begin{array}{l}\text { Unknown } \\
\text { Normally highly unstable } \\
\text { protein }\end{array}$ & $\begin{array}{l}\text { Zhong et al. 2005; Chou et al. } \\
\quad 2006\end{array}$ \\
\hline Bcl-w & $\begin{array}{l}\text { Noncanonical tail anchor } \\
\text { Localization unknown }\end{array}$ & Unknown & $\begin{array}{l}\text { Hinds et al. 2003; Wilson- } \\
\text { Annan et al. } 2003\end{array}$ \\
\hline A1/Bfl-1 & $\begin{array}{l}\text { Charged carboxyl terminus } \\
\text { MOM (other membranes?) } \\
\text { and perinuclear region }\end{array}$ & Unknown & Simmons et al. 2008 \\
\hline Bim & $\begin{array}{l}\text { TOM complex-dependent } \\
\text { carboxy-terminal } \\
\text { hydrophobic segment- } \\
\text { MOM }\end{array}$ & $\begin{array}{l}\text { Associated with microtubules } \\
\text { in healthy cells }\end{array}$ & $\begin{array}{l}\text { O'Connor et al. 1998; Weber } \\
\text { et al. } 2007\end{array}$ \\
\hline Puma & $\begin{array}{l}\text { Carboxy-terminal hydrophobic } \\
\text { segment (?)—MOM }\end{array}$ & $\begin{array}{l}\text { Unknown } \\
\text { Transcriptionally regulated by } \\
\text { p53 }\end{array}$ & Nakano and Vousden 2001 \\
\hline Bad & $\begin{array}{l}\text { Two lipid-binding domains at } \\
\text { carboxyl terminus } \\
\text { Cytosolic in healthy cells, } \\
\text { mitochondrial in apoptotic } \\
\text { cells }\end{array}$ & $\begin{array}{l}\text { Regulation of glucose } \\
\text { metabolism }\end{array}$ & $\begin{array}{l}\text { Hekman et al. 2006; Danial } \\
\quad 2008\end{array}$ \\
\hline $\mathrm{Bik} / \mathrm{Blk}$ & $\begin{array}{l}\text { Carboxy-terminal tail anchor } \\
\text { Hydrophobic segment_-ER }\end{array}$ & Unknown & Germain et al. 2002 \\
\hline
\end{tabular}


A. Shamas-Din et al.

\begin{tabular}{|c|c|c|c|}
\hline $\begin{array}{l}\mathrm{Bcl}-2 \\
\text { protein }\end{array}$ & $\begin{array}{l}\text { Targeting mechanism } \\
\text { and location }\end{array}$ & Nonapoptotic function & References \\
\hline Noxa & $\begin{array}{l}\text { Targeting region at carboxyl } \\
\text { terminus and via } \mathrm{BH} 3 \text { region } \\
\text { mediated interactions with } \\
\text { Mcl-1-MOM }\end{array}$ & Unknown & $\begin{array}{l}\text { Oda et al. 2000; Ploner et al. } \\
\quad 2008\end{array}$ \\
\hline $\mathrm{Bmf}$ & $\begin{array}{l}\text { By binding to Bcl-2 family } \\
\text { members? } \\
\text { MOM during apoptosis }\end{array}$ & $\begin{array}{l}\text { Binds myosin } \mathrm{V} \text { motors by } \\
\text { association with dynein light } \\
\text { chain } 2 \text { in healthy cells } \\
\text { Function unknown }\end{array}$ & Puthalakath et al. 2001 \\
\hline $\begin{array}{l}\text { Hrk/ } \\
\text { DP5 }\end{array}$ & $\begin{array}{l}\text { Tail anchor } \\
\text { MOM }\end{array}$ & $\begin{array}{l}\text { Role in hearing loss in response } \\
\text { to gentamycin suggests } \\
\text { function in inner ear }\end{array}$ & $\begin{array}{l}\text { Inohara et al. 1997; Kalinec } \\
\text { et al. } 2005\end{array}$ \\
\hline Beclin-1 & $\begin{array}{l}\text { Carboxy-terminal dependent? } \\
\text { ER, MOM, trans-Golgi } \\
\quad \text { network }\end{array}$ & Regulates autophagy & Sinha and Levine 2008 \\
\hline
\end{tabular}

change in this preexisting channel, such that it is linked to ANT (Shimizu et al. 1999). However, by biochemical and gene knockout studies, all three components of the PTP have been shown to be dispensable for Bax-dependent MOMP (Tsujimoto and Shimizu 2007). Nevertheless, PTP formation by Bax/Bak-independent mechanisms does have a role in cell death by regulating necrosis in some circumstances (Nakagawa et al. 2005).

An alternative possibility is that activated Bax/Bak form pores directly in the MOM. Amphipathic $\alpha$-helical peptides can porate membranes via two separate mechanisms termed barrel-stave or toroidal, leading to two distinct pores, proteinaceous or lipidic, respectively (Yang et al. 2001). In both models, the helices line the pore, perpendicular to the membrane. The barrel-stave model creates a proteinaceous pore devoid of lipids. Conversely, a toroidal pore is composed of protein and lipid components. Bax inserts three amphipathic helices (5, 6, and 9) into the MOM before oligomerization and MOMP (Annis et al. 2005). Currently, there is evidence for Bax and Bak generating both proteinaceous and lipidic pores. Electrophysiological studies using patch clamping identified a pore that was termed the mitochondrial apoptosis-induced channel (MAC) (Pavlov et al.
2001). The MAC contains oligomeric Bax or Bak, providing the first indication that these proteins can create a proteinaceous pore (Dejean et al. 2005). This complex is thought to be composed of nine Bax or Bak monomers yielding a pore diameter of $\sim 5 \mathrm{~nm}$, which should be sufficient to release cytochrome $c$, a $15-\mathrm{kDa}$ protein. However, experiments investigating the core mechanism of Bax pore formation using liposomes or MOMs show that Bax can release high-molecular-weight dextrans up to $2000 \mathrm{kDa}$ (Kuwana et al. 2002), suggesting that the pore is likely larger in vivo. Furthermore, Bax can create pores ranging in size from 25 to $100 \mathrm{~nm}$, consistent with a lipidic pore, not a proteinaceous pore (Schafer et al. 2009). Additionally, peptides containing only helices 5 and 6 of Bax can cause pores to form in liposomes that resemble lipidic pores (Qian et al. 2008). Most of the evidence for proteinaceous pores has been observed with isolated mitochondria, whereas the evidence for lipidic pores is largely from experiments with liposomal-based systems. It is therefore conceivable that both mechanisms are operative at different steps in vivo: Bax or Bak may initially insert helices 5 and 6 (and 9) into the MOM, forming small pores that resemble proteinaceous pores, and after further oligomerization, the pores increase 
in size and alter the lipid structure of the membrane, facilitating the formation of a pore that can release larger IMS proteins such as OMI/HTRA2 ( $49 \mathrm{kDa})$ and SMAC/DIABLO $(\sim 27 \mathrm{kDa})$.

\section{Mechanism of Bax/Bak Activation and Pore Formation}

A conformational change in the amino-terminal region of both Bax and Bak has been detected that correlates with activation (Hsu and Youle 1997; Griffiths et al. 1999; Dewson et al. 2009). When Bax interacts transiently with membranes, it exposes an amino-terminal epitope that can be detected using the 6A7 monoclonal antibody (Hsu and Youle 1997; Yethon et al. 2003). After interacting with $\mathrm{BH} 3$ proteins that cause membrane insertion of Bax, the epitope change detected by 6A7 is "locked in"; that is, it is no longer reversible. The exposure of the 6A7 epitope has been attributed to a conformational change in $\alpha$ helix 1 of Bax (Peyerl et al. 2007). The sequence of events is likely different for the amino-terminal conformational change in Bak because the protein is constitutively membrane bound.

After activation, the next step leading to oligomerization and pore formation is still under debate. Recently, a second hydrophobic pocket of Bax was identified through binding with the $\mathrm{BH} 3$ peptide of Bim (Gavathiotis et al. 2008, 2010). This new binding surface termed the "rear pocket" is composed of helices 1 and 6 and is located on the opposite side from the canonical "front" $\mathrm{BH} 3$-binding pocket of Bax (composed of helices 2-4). In the cytoplasmic form of Bax, the rear pocket is masked by an unstructured loop between helices 1 and 2, much as the front pocket is masked by helix 9. If the helix 1-2 loop is tethered to the rear pocket, Bax cannot expose the 6A7 epitope or release helix 9 from the front pocket, rendering Bax inactive. This suggests that Bax needs to undergo multiple conformational changes to bind to membranes and oligomerize to form pores. Bax and Bak also contain two more putatively transmembrane regions located in helices 5 and 6. After activation, Bax inserts helices
5, 6, and 9 into the MOM (Annis et al. 2005). In contrast, helix 9 of Bak is constitutively transmembrane, and Bak inserts (at least) $\alpha 6$ into the MOM after activation (Oh et al. 2010). Additionally, Bak lacking its carboxy-terminal transmembrane domain is still able to insert into membranes and oligomerize, causing pore formation after activation by $\mathrm{BH} 3$ proteins ( $\mathrm{Oh}$ et al. 2010; Landeta et al. 2011). Thus, one or more domains of Bak in addition to helix 9 must be anchoring it within the membranes. Further studies are required to determine whether Bak inserts both helices 5 and 6 , as appears to be the case for Bax.

Whether it binds to the "front" or the "rear" pocket, the $\mathrm{BH} 3$ region located in $\alpha$ helix 2 of both Bax and Bak is essential for homodimerization (George et al. 2007; Dewson et al. 2008). Two models of how the proapoptotic poreforming proteins propagate the dimers into larger pore-forming oligomers have emerged. The asymmetric and symmetric dimer models both propose that Bax and Bak monomers interact via their $\mathrm{BH} 3$ regions and helix 6; however, they differ in which pockets the proteins use to oligomerize beyond the dimer (Fig. 3). The asymmetrical dimer model was proposed after the identification of the rear pocket (Gavathiotis et al. 2008, 2010). In this model, activator $\mathrm{BH} 3$ proteins initiate the activation of Bax by binding to the rear pocket, causing allosteric conformational changes that displace helix 9, which allows Bax to target to the MOM (Kim et al. 2009). Sequential oligomerization proceeds by the $\mathrm{BH} 3$ region of an activated $\mathrm{Bax}$ binding to the rear pocket of another Bax monomer, thereby exposing its $\mathrm{BH} 3$ region to further propagate oligomerization.

The second model proposes that Bax forms symmetrical dimers whereby the $\mathrm{BH} 3$ regions of two Bax monomers reciprocally bind the front pockets of each other (Dewson et al. 2009; Bleicken et al. 2010; Oh et al. 2010; Zhang et al. 2010). This dimerization changes the conformation of Bax such that the rear pockets interact with each other to facilitate oligomerization.

These contrasting models postulate different "units" that are joined to form the oligomer. However, it is clear that in each model both 
A. Shamas-Din et al.

A Symmetrical dimerization

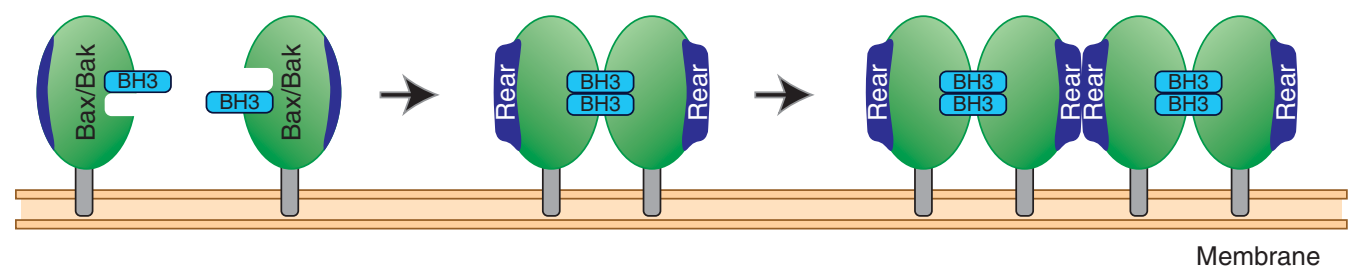

B Asymmetrical dimerization

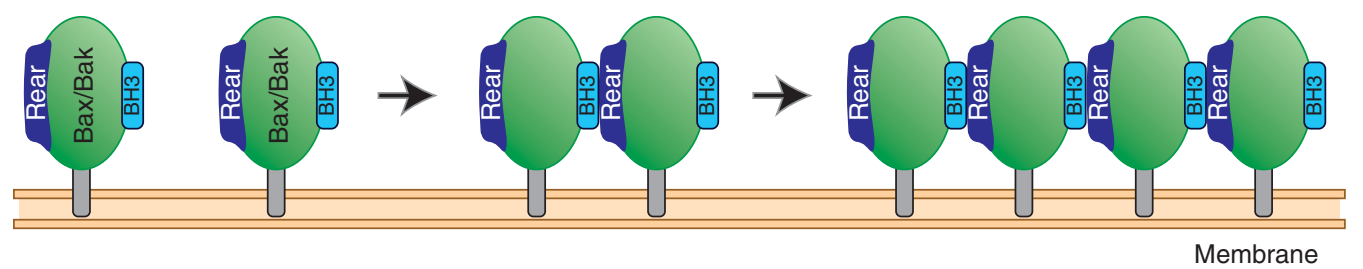

Figure 3. Models of Bax and Bak dimer formation. (A) Symmetrical dimers: Active Bax and Bak monomers with helices embedded within the MOM expose their BH3 regions, which, in turn, bind to the "front pocket" composed of the hydrophobic $\mathrm{BH} 1-3$ groove of an adjacent monomer. This binding changes the conformation of the "rear pocket" composed of helices 1 and 6, allowing homodimers to form tetramers and further propagate oligomerization. (B) Asymmetrical dimers: Active Bax and Bak expose their BH3 regions, which interact with the rear pocket on an adjacent monomer, forming an oligomer through subsequent rear pocket:BH3 region interactions.

hydrophobic pockets are important for the proapoptotic function of the proteins. Identification of the mechanism and dynamic binding surfaces that mediate oligomerization will be a great asset for assays testing small-molecule modulators of Bax and Bak function to allow this rate-limiting step in apoptosis to be selectively activated or inhibited as dictated by clinical need.

\section{BH3 MEMBERS}

\section{Evolution and Structure of BH3 Proteins}

$\mathrm{BH} 3$ proteins interact with and regulate multiregion proapoptotic and antiapoptotic Bcl-2 family members through the $\mathrm{BH} 3$ region, a shared homology region with other Bcl-2 family proteins. The specificity and affinity of the $\mathrm{BH} 3$ proteins for binding with their partners are determined by small differences in the amino acid sequence in the $\mathrm{BH} 3$ region (Table 1). Mutations in one or more of the key residues in the
BH3 region of Bid and Bad can abolish binding with other Bcl-2 family proteins and impede their proapoptotic function (Wang et al. 1996; Zha et al. 1997).

The evolutionary relationship between multiregion $\mathrm{Bcl}-2$ family members and $\mathrm{BH} 3$ proteins is distant, and $\mathrm{BH} 3$ proteins are thought to have originated after an expansion event during vertebrate evolution (Aouacheria et al. 2005). A subclass of $\mathrm{BH} 3$ proteins, Bnip proteins, has a different evolutionary history and likely originated independently. These Bnip proteins contain a less well-conserved $\mathrm{BH} 3$ region and may not require this to bind to other Bcl-2 family proteins (Chinnadurai et al. 2008).

NMR studies of Bim, Bad, and Bmf, and in silico predictions for other $\mathrm{BH} 3$ proteins indicate that they are intrinsically unstructured proteins in the absence of binding partners but undergo localized conformational changes in the $\mathrm{BH} 3$ region upon binding with antiapoptotic proteins (Hinds et al. 2007). Bid is an exception to this observation, because it shares 
phylogenetic, structural, and functional features with multiregion Bcl-2 family members (Billen et al. 2009). Bid was originally discovered through binding to both Bax and Bcl-2 and was classified as a proapoptotic "BH3-only" protein because it contained only a $\mathrm{BH} 3$ region. However, Bid shares a high degree of similarity in the overall three-dimensional (3D) fold of the structure with other multiregion $\mathrm{Bcl}-2$ family proteins (Chou et al. 1999; McDonnell et al. 1999). Furthermore, the presence of a newly identified BH4 region (Kvansakul et al. 2008), phylogenetic evidence, and the mechanistic parallels between the activation of $\mathrm{Bid}$ and Bax suggest that Bid is more closely related to the multiregion family proteins than the $\mathrm{BH} 3$ proteins (Billen et al. 2009; Shamas-Din et al. 2011).

\section{Structural Plasticity and Multiple Members Permits Diversity in Function}

Although there are five major antiapoptotic and two main proapoptotic multiregion proteins, there are at least 10 different $\mathrm{BH} 3$ proteins in the vertebrate genome (Aouacheria et al. 2005). The amplification of the $\mathrm{BH} 3$ protein subgroup allows the organism to induce apoptosis selectively by monitoring many different types of cell stress that may be restricted to certain subcellular sites, specific cell types, or signaling pathways. Accordingly, there are many ways to turn on the different $\mathrm{BH} 3$ proteins, including transcriptional, translational, and posttranslational mechanisms. Furthermore, the consequence of turning on specific $\mathrm{BH} 3$ proteins differs according to the binding specificity of the $\mathrm{BH} 3$ region for its "target" (Table 1). According to the direct activation model, these quantitative differences in binding affinities lead to qualitative differences in function. Only a restricted subclass (so far only tBid, Bim, and Puma) has high enough affinity for the multiregion proapoptotic proteins Bax and Bak to allow direct binding and activation as discussed above. These $\mathrm{BH} 3$ proteins are thus designated "activators." In contrast, all other $\mathrm{BH} 3$ proteins have been proposed to act as "sensitizers" and displace activator $\mathrm{BH} 3$ proteins from binding to antiapoptotic members. This frees the activator $\mathrm{BH} 3$ proteins to then bind to Bax/Bak. Sensitizer binding also prevents antiapoptotic proteins binding activated Bax and Bak. Thus, sensitizer $\mathrm{BH} 3$ proteins specifically bind to antiapoptotic members and do not bind to Bax/ Bak directly. In subclassifying the $\mathrm{BH} 3$ proteins, the role of Puma remains somewhat controversial, because it has been shown to be either an activator (Cartron et al. 2004; Kim et al. 2006, 2009; Gallenne et al. 2009) or a sensitizer in different studies (Kuwana et al. 2005; Certo et al. 2006; Chipuk et al. 2008; Jabbour et al. 2009). This controversy may be caused by the fact that $\mathrm{BH} 3$ activators can also act as sensitizers via mutual sequestration of antiapoptotic proteins (as discussed above).

The inherent structural plasticity of most $\mathrm{BH} 3$ proteins also facilitates interactions with multiple binding partners, including non-Bcl2 proteins that govern their "day jobs" (i.e., $\mathrm{BH} 3$ proteins in their nonactivated state have roles independent of apoptosis). To further facilitate the "day jobs," constitutively expressed BH3 proteins are located in parts of the cell distant from their apoptosis target membrane(s), where they participate in various nonapoptotic cellular processes (Table 2). Thus, to switch the function of $\mathrm{BH} 3$ proteins from the "day jobs" to apoptosis, constitutively expressed proteins undergo posttranslational modifications, such as phosphorylation, myristoylation, ubiquitination, and proteolysis, that restrict the proteins to one of the alternative functions (Kutuk and Letai 2008). In addition, the function of $\mathrm{BH} 3$ proteins such as Puma and Noxa are controlled at the transcriptional level and are expressed only in the presence of death stimuli. Finally, the $\mathrm{BH} 3$ proteins can change their conformation at their target membrane(s) and upon binding to Bcl-2 family partner to change their function.

BH3 Proteins Binding to Membranes as a Critical Step in Regulating Apoptosis

For the amplification of death signals, $\mathrm{BH} 3$ proteins translocate to the MOM to activate Bax and Bak and promote MOMP. However, the exact 
mechanism by which different $\mathrm{BH} 3$ proteins migrate to and insert into membranes varies. Mitochondrial-targeting and tail-anchor sequences are used to target several of the $\mathrm{BH} 3$ proteins to the MOM (see Table 2) (Kuwana et al. 2002; Seo et al. 2003; Hekman et al. 2006; Lovell et al. 2008). Moreover, the presence of specific lipids such as cardiolipin and cholesterol (Lutter et al. 2000; Hekman et al. 2006; Lucken-Ardjomande et al. 2008) and protein receptors such as Mtch2 at the MOM have been shown to influence the targeting of other Bcl-2 family proteins to their target membranes (Zaltsman et al. 2010).

Once at the membrane, it is likely that $\mathrm{BH} 3$ proteins undergo extensive conformational changes that dictate their function. For example, after cleavage by activated caspase- 8 , initial association of cleaved Bid with the MOM causes separation of the two fragments, with subsequent insertion and structural rearrangement of the p15 fragment (tBid) that likely orients the $\mathrm{BH} 3$ region to bind to Bax or Bcl-XL. Furthermore, the other $\mathrm{BH} 3$ proteins that are intrinsically unstructured undergo localized conformational changes upon binding membranes and antiapoptotic proteins.

Despite strong evidence for the functional interaction and activation of Bax and Bak by activator $\mathrm{BH} 3$ proteins, demonstration of binding of the full-length protein (as opposed to peptides from the $\mathrm{BH} 3$ region) has only recently been reported: Strong reversible binding of tBid to Bax was observed in liposomal MOM-like membranes (apparent $K_{\mathrm{d}} \sim 25 \mathrm{~nm}$ ) (Lovell et al. 2008). Furthermore, when synthesized by in vitro translation, full-length $\mathrm{BH} 3$ proteins tBid, Bim, and Puma induced Bax- and Bakdependent MOMP and shifted monomeric Bax and Bak to higher-order complexes in mitochondria (Kim et al. 2006).

In vitro experiments clearly show that $\mathrm{BH} 3$ proteins recruit and sequester the antiapoptotic $\mathrm{Bcl}-2$ family proteins at the membrane. $\mathrm{BH} 3$ proteins bind the antiapoptotic proteins by docking on the $\mathrm{BH} 3$ region in the hydrophobic groove made of $\mathrm{BH} 1, \mathrm{BH} 2$, and $\mathrm{BH} 3$ regions of the antiapoptotic family proteins (Sattler et al. 1997; Liu et al. 2003; Czabotar et al. 2007). Sim- ilar to the differential binding to proapoptotic family members, experiments in vitro suggest that each $\mathrm{BH} 3$ protein selectively binds a defined range of antiapoptotic proteins that is determined by differences in the structure and flexibility of the hydrophobic pocket of the antiapoptotic proteins, although, to date, these interactions have been measured only with peptides from the different $\mathrm{BH} 3$ regions rather than the full-length proteins (see Table 1).

\section{ANTIAPOPTOTIC MEMBERS}

Structure of Family Members Alone and in Complex with $\mathrm{BH} 3$ Peptides

Early observations that specific mutations in Bcl-2 abrogated both antiapoptotic function and binding to $\mathrm{Bax}$ and the presence of $\mathrm{BH} 3$ regions in both classes of the proapoptotic $\mathrm{Bcl}-2$ families that bind $\mathrm{Bcl}-2$ as "ligands" led to the concept of a receptor surface on $\mathrm{Bcl}-2$. However, it was hard to confirm the details of this binding interaction using structural studies because of difficulties with purifying recombinant full-length $\mathrm{Bcl}-2$. Initial success arose from NMR studies on Bcl-XL lacking its hydrophobic carboxyl terminus (Muchmore et al. 1996), which is similar to the structure obtained for Bax (Suzuki et al. 2000), was shown to contain two hydrophobic helices (5 and 6) forming a central hairpin structure surrounded by the remaining six amphipathic helices. Thereafter, cocrystals of "tail-less" Bcl-XL with BH3 peptides derived from Bak and Bim identified the $\mathrm{BH} 3$-binding surface as a hydrophobic cleft formed by noncontiguous residues in $\mathrm{BH}$ regions 1-3 (involving parts of helices 2, 7-8, and 4-6, respectively) (Sattler et al. 1997; Liu et al. 2003). These structural observations provided the platform for measurements of the many potential interactions between the binding pockets of different antiapoptotic members and the $\mathrm{BH} 3$ regions of the proapoptotic family members. These differing binding affinities cluster into functional groupings (e.g., binding to multiregion vs. $\mathrm{BH} 3$ proteins, or activators vs. sensitizers) (Table 1) with functional consequences as elucidated below. 
Multiple Mechanisms of Action of Bcl-XL: Evidence of Binding to Both Multiregion and $\mathrm{BH} 3$ Members

Measurements of the affinity of binding between individual pairs of antiapoptotic family members and $\mathrm{BH} 3$ peptides in solution provide valuable clues about functional relevance. However, in cells, most of these interactions occur at or within intracellular membranes, and, indeed, the final commitment step in apoptosis being regulated is MOMP. Thus, experiments using recombinant full-length proteins or proteins synthesized in vitro, and isolated mitochondria or liposomes, have been critical in translating these interactions into testable models. For practical reasons, such experiments are most feasible using recombinant Bcl-XL, because other antiapoptotic proteins are much more difficult to purify in sufficient quantities owing to problems with aggregation (e.g., Bcl-2) or marked protein instability (e.g., Mcl-1). Thus, details about the mechanism of action of $\mathrm{Bcl}-\mathrm{XL}$ serve as a model for the other proteins, acknowledging that other members will differ in some aspects, as discussed below.

By examining membrane permeabilization in a system with recombinant $\mathrm{Bcl}-\mathrm{XL}, \mathrm{Bax}$, and tBid (both wild type and a mutant form that is unable to bind to Bcl-XL, but still activates Bax), it was shown that Bcl-XL inhibits MOMP not only directly by binding to tBid but also by binding to membrane-bound Bax (Billen et al. 2008). Thus, both of the major interactions postulated by the competing direct activation and displacement models contribute to inhibition of apoptosis. Furthermore, other mechanisms of action of Bcl-XL independent of these binding interactions were also identified, including prevention of Bax insertion into membranes as perhaps the most potent mechanism. This initially contentious point has been recently supported by observations that Bax undergoes multiple conformational changes that ultimately lead to oligomerization and MOMP, but the first of these steps is the exposure of the amino terminus at the membrane in a reversible equilibrium (Edlich et al. 2011). Bcl-XL changes this equilibrium such that Bax is shifted out of the conformation that binds it loosely to membranes. Moreover, consistent with the postulation that dynamic conformational changes are a feature of all three $\mathrm{Bcl}-2$ families, these investigators observed that $\mathrm{Bcl}-\mathrm{XL}$ also undergoes reversible conformational changes that allow it to come on and off the MOM without being inserted. The structural basis of this mechanism is unclear, although it is speculated that sequestering of the opposite partner's carboxy-terminal helix 9 in the $\mathrm{BH} 3$-binding groove may mediate this effect. In essence, helix 9 of the other protein acts as an (inactive) $\mathrm{BH} 3$ mimetic.

Taken together, these observations have identified multiple mechanisms that contribute to the ultimate function of Bcl-XL. Using defined amounts of proteins with an in vitro system allows measurement of the stoichiometry of inhibition and indicates that one Bcl-XL can inhibit approximately four Bax molecules. Therefore, as a conceptual overview, the functions of Bcl-XL can be most simply summarized as a dominant-negative Bax, where it is able to undergo many of the binding interactions that Bax does but does not make the final conformational change that allows it to bind to other $\mathrm{Bcl}$ $\mathrm{XL} / \mathrm{Bax}$ molecules and oligomerize to form a pore. In accordance with the postulated models of oligomerization discussed above, this would imply that activated Bcl-XL cannot form a rear pocket in the analogous regions described for Bax/Bak.

\section{Mediators of Multiple Mechanisms: Membrane Binding and Conformational Changes}

Similar to Bax and Bak, there is evidence that the antiapoptotic Bcl-2 family proteins adopt multiple conformations in associating with membranes. Bcl-2 initially inserts helix 9 into the membrane, but after binding to tBid or a $\mathrm{BH} 3$ peptide derived from Bim, helix 5 moves to a hydrophobic environment consistent with insertion into the membrane (Kim et al. 2004). Therefore, it is plausible that $\mathrm{Bcl}-\mathrm{XL}$ also adopts multiple conformations that are dictated by its interaction both with membranes and other 
A. Shamas-Din et al.

Bcl-2 family members that shift the dynamic equilibrium between the different forms. Specifically, the data suggest that there is a form that is loosely bound to membranes (form 1), another in which helix 9 is inserted into membranes but not other helices (form 2), and, finally, a form in which helix 9 as well as helices 5 and 6 are inserted into the membrane (form 3 ) (Fig. 4). It is possible that these different conformations independently mediate the different mechanisms of action of Bcl-XL in inhibiting the final process of pore formation by activated Bax. Such a scheme is also compatible with observations that mutations that do not affect the BH3-binding pocket can still enhance antiapoptotic function, either by forcing constitutive membrane insertion (into forms 2 or 3 ) by replacing the endogenous tail-anchor sequence (Fiebig et al. 2006), or by loosening intramolecular binding, thereby "freeing" helices 5 and 6 to insert into membranes (form 3) (Asoh et al. 2000).

\section{Comparison of Different Antiapoptotic Members}

In simpler organisms such as Caenorhabditis elegans and Drosophila, there is only one inhibitory Bcl-2 family member, whereas in vertebrates there are at least four. There are potentially multiple reasons for this redundancy. One that is firmly grounded on structural studies indicates that the different antiapoptotic family members bind to (and sequester) the multiple BH3 members differentially, including the multidomain proapoptotic members alluded to previously. Responding to multiple $\mathrm{BH} 3$ proteins allows fine-tuning of inhibitory responses in mammalian cells to different types of stress that "activate" specific BH3 proteins. Such a system provides multifactorial responses much more diverse than those in simpler eukaryote cells. Characterization of the differences in binding has received much attention and is conferred by the distinct sequence of each $\mathrm{BH} 3$ region that shares a propensity to form an amphipathic helix containing four hydrophobic residues, and the topology of the $\mathrm{BH} 3$-binding groove on the antiapoptotic "receptor." Peptides from certain $\mathrm{BH} 3$ regions like Bim bind with high affinity to all the antiapoptotic and apoptotic multiregion members, whereas others like Bad and Noxa are more selective (highly preferential binding to Bcl-2/Bcl-XL/Bcl-w or Mcl-1/Bfl-1, respectively). Some of this specificity is explained by well-defined requirements, for example, any amino acid at the fourth hydrophobic position in the $\mathrm{BH} 3$ region will bind to Mcl-1, which has a shallow, open pocket for this residue, as opposed to $\mathrm{Bcl}-\mathrm{XL}$, which does not accommodate charged or polar residues at this position (Lee et al. 2009; Fire et al. 2010). Other features also contribute; the higher global flexibility of Bcl-XL creates a pliable pocket for diverse $\mathrm{BH} 3$ mimetics compared with the deeper hydrophobic pocket with a rigid angle of entry in Mcl-1 that restricts binding to specific BH3 proteins (Lee et al. 2009).

As a consequence, no single antiapoptotic member binds to all $\mathrm{BH} 3$ proteins in vitro, as assessed by biophysical measurements (see Table 1). These measurements have been largely (although not entirely) confirmed by experiments in transfected cell lines where overexpression of single antiapoptotic proteins confers protection against apoptosis mediated by the $\mathrm{BH} 3$-binding partners identified in vitro. The discrepancy noted in a few experiments is likely because of the fact that in cells these interactions between full-length proteins occur on membranes rather than in the cytoplasm, and membrane binding may modify protein-protein interactions either allosterically or by posttranslational modifications altering the binding surfaces (Feng et al. 2009) or affecting the orientation and proximity of the binding surfaces.

Multiple antiapoptotic proteins also allow differential control of processes relevant to cell death independent of $\mathrm{BH} 3$-binding-pocket interactions. The $\mathrm{BH} 4$ region of $\mathrm{Bcl}-2$ binds to the regulatory and coupling domain of the inositol 1,4,5 triphosphate (IP3) receptor that controls calcium efflux from the ER, thereby inhibiting the initiation phase of calcium-mediated apoptosis (Rong et al. 2009). A residue critical for this binding interaction in Bcl-2 (Lys17) is not conserved in the $\mathrm{BH} 4$ domain of $\mathrm{Bcl}-$ $\mathrm{XL}$ (Asp11), rendering the latter ineffective at 


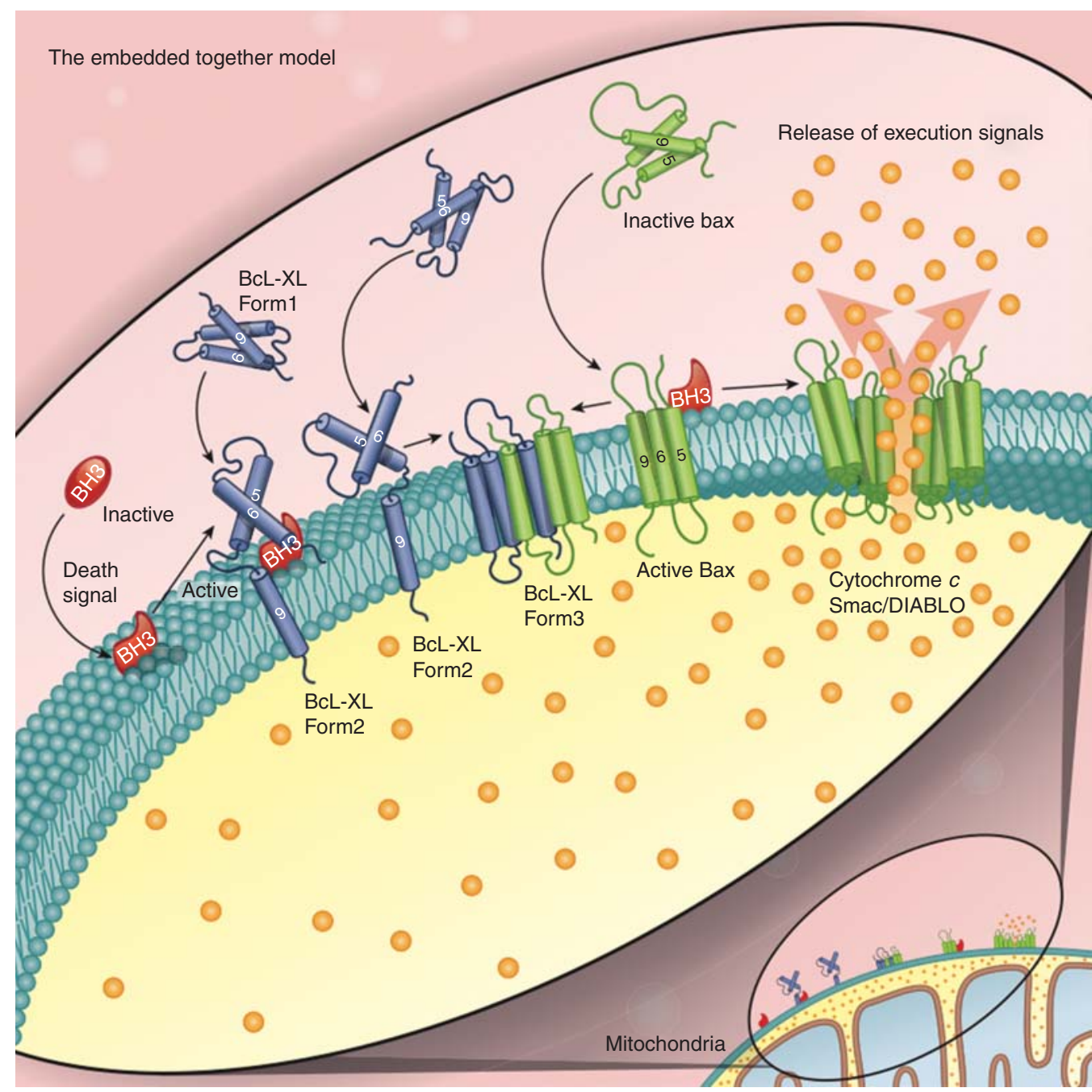

Figure 4. Schematic overview of the embedded together model. The role of the membrane is highlighted as the "locus of action" where the effects of the interactions between the Bcl-2 family members are manifest. After the cell receives a death signal, an activator $\mathrm{BH} 3$ protein migrates to and inserts into the MOM, where it recruits cytoplasmic Bax. Bax undergoes conformational changes at membranes that allow it to respond to chemical changes in the cell such as the generation of reactive oxygen species, ion concentration, and $\mathrm{pH}$. Membranebound Bax or Bak changes its conformation such that they oligomerize, leading to MOMP and/or recruit other cytoplasmic Bax. Both the activator and the sensitizer BH3 proteins sequester the antiapoptotic proteins (such as Bcl-XL) by recruiting and strongly binding to them at the MOM, thereby preventing the inhibition of Bax and Bak. Bcl-XL changes its conformation depending on its binding partner. Upon binding to a BH3 protein or Bax/ Bak, Bcl-XL changes from form 1 (cytoplasmic or loosely attached to the MOM) to form 2 (helix 9 inserted into MOM) or to form 3 (helices 5, 6, and 9 bound to or inserted into MOM), respectively. It is likely that form 2 binds primarily $\mathrm{BH} 3$ proteins but also recruits additional Bcl-XL to the membrane, whereas form 3 binds primarily Bax and Bak. No function has yet been ascribed to Bcl-XL form 1, although one is likely. Thus, by causing the proteins to adopt different conformations, the membrane regulates their function in determining the fate of the cell. Unlike other models that propose unidirectional interactions, in this model, all of the functional interactions are governed by dynamic equilibria of protein-membrane and protein-protein interactions. 
A. Shamas-Din et al.

inhibiting IP3-mediated calcium release (Monaco et al. 2011).

Another reason for the diversity of antiapoptotic proteins beyond specificity conferred by different binding partners is the control of subcellular localization. In particular cell types, there may be a benefit to having Bcl-2 family members constitutively present on membranes such as is the case with Bcl-2, as opposed to BclXL, Mcl-1, Bfl-1, and Bcl-w, all of which must undergo a conformational change before inserting into the membrane. In $\mathrm{Bcl}-2$, it is presumed that the carboxy-terminal region that is necessary and sufficient for membrane insertion (Janiak et al. 1994) is not bound to other hydrophobic regions of the protein once it is synthesized and can therefore mediate direct membrane insertion. In the other antiapoptotic proteins, the carboxy-terminal tail is sequestered until the protein is activated. Even within this group, there are different strategies that control membrane localization. Unlike the other family members, Bfl-1 does not have a hydrophobic region at the carboxyl terminus that mediates membrane insertion but has an amphipathic helix (Brien et al. 2009). Bcl-XL is thought to exist as a homodimer in the cytoplasm, where the carboxy-terminal tail is bound reciprocally to a hydrophobic groove in the dimer partner (Jeong et al. 2004). The longer carboxy-terminal helix 8 of Bcl-w binds in its own $\mathrm{BH} 3$-binding pocket and can be displaced by $\mathrm{BH} 3$ peptides to allow membrane insertion (Hinds et al. 2003; Wilson-Annan et al. 2003), a mechanism reminiscent of Bax. Before apoptosis is elicited, Mcl-1 is constitutively loosely associated with mitochondria by an EELD motif in the amino-terminal portion, which can bind to the mitochondrial import receptor Tom70 (Chou et al. 2006). For all the antiapoptotic proteins, deletion of the carboxy-terminal $\alpha$ helix decreases function, presumably by preventing assumption of forms 2 and 3 on the membrane where many of the relevant binding partners are localized. Furthermore, attachment of the inhibitor to the membrane increases the probability of interaction by increasing local concentration and the viscosity of the membranes restricting diffusion. A third justification for diversity of antiapoptotic proteins is the benefit of varying regulation of protein abundance as a way of fine-tuning apoptosis. The $b c l$ 2 gene contains two estrogen response elements controlling expression in breast tissue. $\mathrm{Bcl}-2$ is a long-lived protein whose expression does not change appreciably even during advanced stages of stress, partly because of the presence of an internal ribosome entry site (IRES) in the $5^{\prime}$ UTR that permits cap-independent translation (Willimott and Wagner 2010). The stability of the $\mathrm{Bcl}-2$ transcript is positively regulated by the RNA-binding protein nucleolin, and negatively regulated by the microRNAs mi-R15a and 16-1 (Willimott and Wagner 2010). Bcl-XL protein levels are more variable and increase acutely in response to internal stress and extracellular signals, mediated by the Jak-STAT and rel/NF-кB pathways (Grad et al. 2000). In contrast, Mcl-1 is an extremely short-lived protein with rapid turnover tightly regulated by a complex cascade of phosphorylation-dependent deubiquitination by USPX9 (Schwickart et al. 2010) that reverses the ubiquitination and subsequent proteasomal degradation mediated by the $\mathrm{BH} 3$ protein E3 ubiquitin ligase MULE/ARF-BP1 (Zhong et al. 2005).

The consequences of these variations in the structure of binding pockets (control of subcellular localization and dynamic protein levels), is that despite sharing the core mechanism of inhibition, each antiapoptotic protein has a distinct personality. This is evident in the specific profile of expression of the proteins in different cell types and organs in whole animals, with the result that each protein has different physiological roles that are apparent in the phenotypes of the knockout mice with different antiapoptotic members (for review, see Hardwick and Soane 2013).

\section{PERSPECTIVE AND FUTURE PROSPECTS}

This brief overview illustrates the enormous growth in our understanding of the mechanisms behind the pivotal role that the $\mathrm{Bcl}-2$ family plays in regulating apoptosis since the original identification of Bcl-2 as a chromosome translocation partner in human B-cell 
Mechanisms of Action of Bcl-2 Family Members

follicular lymphoma. We are now at a stage where this understanding is yielding practical results, as several drugs mimicking $\mathrm{BH} 3$ regions that bind to Bcl-2 and Bcl-XL are in late-stage clinical trials as cancer agents to elicit or enhance chemotherapy-induced apoptosis. The recognition that there are distinct binding profiles for each antiapoptotic protein that arose from fundamental studies has now motivated the search for other small molecules to expand the therapeutic tool kit (Stewart et al. 2010), so that in the future we will be able to target every antiapoptotic protein.

To date, most attention has been paid to the role of the Bcl-2 family in regulating MOMP because of the well-characterized consequences of releasing IMS proteins in activating caspases. However, it is increasingly apparent that the ER is the site of many important processes that determine cell death and survival in which the $\mathrm{Bcl}-2$ family is intimately involved. Aside from controlling calcium flux (Rong et al. 2009) and regulating the activity of Beclin-1 to initiate autophagy (see Mah and Ryan 2012; Nixon and Yang 2012), other death pathways are also inhibited by Bcl-2 at the ER (Germain et al. 2002). Beyond this, there is also evidence that a portion of the antiapoptotic activity of $\mathrm{Bcl}-2 /$ $\mathrm{Bcl}-\mathrm{XL}$ does not depend on binding to and inhibiting the other two proapoptotic families (Minn et al. 1999). One recent study suggests that this mechanism involves regulation of $\mathrm{cy}$ toplasmic levels of acetyl-CoA as a substrate for protein $\alpha$-acetylation (Yi et al. 2011). Elucidating potential binding partners that mediate this pathway is an important target of future research.

Our basic understanding of the core mechanism of the regulation of membrane permeabilization by Bcl-2 family members has passed from the stage of phenomenology to testable descriptions of mechanism. The next hurdle will be to extend quantitative measurements of the binding interactions that have been measured in vitro to what happens in organelles and in cells. This will allow further refinement and elaboration of exciting preliminary mathematical models of the control of apoptosis in whole cells (Spencer and Sorger 2011).

\section{ACKNOWLEDGMENTS}

Funding for the research in the Andrews and Leber laboratories was provided by a grant from the Center for Health Information and Research (FRN 12517). D.W.A. holds the Canada Research Chair in Membrane Biogenesis, A.S.-D. holds an Ontario Graduate Studentship, and J.K. holds a research fellowship from the Canadian Breast Cancer Foundation-Ontario Region.

\section{REFERENCES}

${ }^{*}$ Reference is also in this collection.

Annis MG, Soucie EL, Dlugosz PJ, Cruz-Aguado JA, Penn LZ, Leber B, Andrews DW. 2005. Bax forms multispanning monomers that oligomerize to permeabilize membranes during apoptosis. EMBO J 24: 2096-2103.

Aouacheria A, Brunet F, Gouy M. 2005. Phylogenomics of life-or-death switches in multicellular animals: Bcl-2, $\mathrm{BH} 3-\mathrm{Only}$, and BNip families of apoptotic regulators. Mol Biol Evol 22: 2395-2416.

Aranovich A, Liu Q, Collins T, Geng F, Dixit S, Leber B, Andrews DW. 2012. Differences in the mechanisms of proapoptotic $\mathrm{BH} 3$ proteins binding to $\mathrm{Bcl}-\mathrm{XL}$ and Bcl-2 quantified in live MCF-7 cells. Mol Cell 45: 754-763.

Asoh S, Ohtsu T, Ohta S. 2000. The super anti-apoptotic factor Bcl-xFNK constructed by disturbing intramolecular polar interactions in rat Bcl-xL. J Biol Chem 275: 37240-37245.

Billen LP, Kokoski CL, Lovell JF, Leber B, Andrews DW. 2008. Bcl-XL inhibits membrane permeabilization by competing with Bax. PLoS Biol 6: e147.

Billen LP, Shamas-Din A, Andrews DW. 2009. Bid: A Baxlike BH3 protein. Oncogene 27 (Suppl 1): S93-S104.

Bleicken S, Classen M, Padmavathi PV, Ishikawa T, Zeth K, Steinhoff HJ, Bordignon E. 2010. Molecular details of Bax activation, oligomerization, and membrane insertion. J Biol Chem 285: 6636-6647.

Brenner C, Grimm S. 2006. The permeability transition pore complex in cancer cell death. Oncogene 25: 4744-4756.

Brien G, Debaud AL, Robert X, Oliver L, Trescol-Biemont MC, Cauquil N, Geneste O, Aghajari N, Vallette FM, Haser R, et al. 2009. C-terminal residues regulate localization and function of the antiapoptotic protein Bfl-1. J Biol Chem 284: 30257-30263.

Brock SE, Li C, Wattenberg BW. 2010. The Bax carboxyterminal hydrophobic helix does not determine organelle-specific targeting but is essential for maintaining Bax in an inactive state and for stable mitochondrial membrane insertion. Apoptosis 15: 14-27.

Brooks C, Wei Q, Feng L, Dong G, Tao Y, Mei L, Xie ZJ, Dong Z. 2007. Bak regulates mitochondrial morphology and pathology during apoptosis by interacting with mitofusins. Proc Natl Acad Sci 104: 11649-11654. 
Cartron PF, Gallenne T, Bougras G, Gautier F, Manero F, Vusio P, Meflah K, Vallette FM, Juin P. 2004. The first $\alpha$ helix of Bax plays a necessary role in its ligand-induced activation by the $\mathrm{BH} 3$-only proteins Bid and PUMA. $\mathrm{Mol}$ Cell 16: 807-818.

Certo M, Del Gaizo Moore V, Nishino M, Wei G, Korsmeyer S, Armstrong SA, Letai A. 2006. Mitochondria primed by death signals determine cellular addiction to antiapoptotic BCL-2 family members. Cancer Cell 9: 351-365.

Chen L, Willis SN, Wei A, Smith BJ, Fletcher JI, Hinds MG, Colman PM, Day CL, Adams JM, Huang DC. 2005. Differential targeting of prosurvival Bcl-2 proteins by their BH3-only ligands allows complementary apoptotic function. Mol Cell 17: 393-403.

Chinnadurai G, Vijayalingam S, Gibson SB. 2008. BNIP3 subfamily BH3-only proteins: Mitochondrial stress sensors in normal and pathological functions. Oncogene 27 (Suppl 1): S114-S127.

Chipuk JE, Fisher JC, Dillon CP, Kriwacki RW, Kuwana T, Green DR. 2008. Mechanism of apoptosis induction by inhibition of the anti-apoptotic BCL-2 proteins. Proc Natl Acad Sci 105: 20327-20332.

Chittenden T, Harrington EA, O'Connor R, Flemington C, Lutz RJ, Evan GI, Guild BC. 1995. Induction of apoptosis by the Bcl-2 homologue Bak. Nature 374: 733-736.

Chou JJ, Li H, Salvesen GS, Yuan J, Wagner G. 1999. Solution structure of BID, an intracellular amplifier of apoptotic signaling. Cell 96: 615-624.

Chou CH, Lee RS, Yang-Yen HF. 2006. An internal EELD domain facilitates mitochondrial targeting of $\mathrm{Mcl}-1$ via a Tom70-dependent pathway. Mol Biol Cell 17: 3952-3963.

Czabotar PE, Lee EF, van Delft MF, Day CL, Smith BJ, Huang DC, Fairlie WD, Hinds MG, Colman PM. 2007. Structural insights into the degradation of Mcl-1 induced by BH3 domains. Proc Natl Acad Sci 104: 6217-6222.

Danial NN. 2008. BAD: Undertaker by night, candyman by day. Oncogene 27 (Suppl 1): S53-S70.

Dejean LM, Martinez-Caballero S, Guo L, Hughes C, Teijido O, Ducret T, Ichas F, Korsmeyer SJ, Antonsson B, Jonas EA, et al. 2005. Oligomeric Bax is a component of the putative cytochrome $c$ release channel MAC, mitochondrial apoptosis-induced channel. Mol Biol Cell 16: 2424-2432.

Dewson G, Kratina T, Sim HW, Puthalakath H, Adams JM, Colman PM, Kluck RM. 2008. To trigger apoptosis, Bak exposes its $\mathrm{BH} 3$ domain and homodimerizes via $\mathrm{BH} 3$ : groove interactions. Mol Cell 30: 369-380.

Dewson G, Kratina T, Czabotar P, Day CL, Adams JM, Kluck RM. 2009. Bak activation for apoptosis involves oligomerization of dimers via their $\alpha 6$ helices. Mol Cell 36: $696-703$.

Dlugosz PJ, Billen LP, Annis MG, Zhu W, Zhang Z, Lin J, Leber B, Andrews DW. 2006. Bcl-2 changes conformation to inhibit Bax oligomerization. EMBO J 25: 2287-2296.

Dumitru R, Gama V, Fagan BM, Bower JJ, Swahari V, Pevny LH, Deshmukh M. 2012. Human embryonic stem cells have constitutively active Bax at the Golgi and are primed to undergo rapid apoptosis. Mol Cell 46: $573-583$.
Edlich F, Banerjee S, Suzuki M, Cleland MM, Arnoult D, Wang C, Neutzner A, Tjandra N, Youle RJ. 2011. Bcl-x(L) retrotranslocates Bax from the mitochondria into the cytosol. Cell 145: 104-116.

Farrow SN, White JH, Martinou I, Raven T, Pun KT, Grinham CJ, Martinou JC, Brown R. 1995. Cloning of a $b c l-2$ homologue by interaction with adenovirus E1B 19 K. Nature 374: 731-733.

Feng Y, Liu D, Shen X, Chen K, Jiang H. 2009. Structure assembly of $\mathrm{Bcl}-\mathrm{x}(\mathrm{L})$ through $\alpha 5-\alpha 5$ and $\alpha 6-\alpha 6$ interhelix interactions in lipid membranes. Biochim Biophys Acta 1788: 2389-2395.

Fiebig AA, Zhu W, Hollerbach C, Leber B, Andrews DW. 2006. Bcl-XL is qualitatively different from and ten times more effective than $\mathrm{Bcl}-2$ when expressed in a breast cancer cell line. BMC Cancer 6: 213 .

Fire E, Gulla SV, Grant RA, Keating AE. 2010. Mcl-1-Bim complexes accommodate surprising point mutations via minor structural changes. Protein Sci 19: 507-519.

Gallenne T, Gautier F, Oliver L, Hervouet E, Noel B, Hickman JA, Geneste O, Cartron PF, Vallette FM, Manon S, et al. 2009. Bax activation by the BH3-only protein Puma promotes cell dependence on antiapoptotic Bcl-2 family members. J Cell Biol 185: 279-290.

Garcia-Saez AJ, Ries J, Orzaez M, Perez-Paya E, Schwille P. 2009. Membrane promotes tBID interaction with BCL(XL). Nat Struct Mol Biol 16: 1178-1185.

Gavathiotis E, Suzuki M, Davis ML, Pitter K, Bird GH, Katz SG, Tu HC, Kim H, Cheng EH, Tjandra N, et al. 2008. BAX activation is initiated at a novel interaction site. Nature 455: 1076-1081.

Gavathiotis E, Reyna DE, Davis ML, Bird GH, Walensky LD. 2010. BH3-triggered structural reorganization drives the activation of proapoptotic BAX. Mol Cell 40: 481-492.

George NM, Evans JJ, Luo X. 2007. A three-helix homooligomerization domain containing $\mathrm{BH} 3$ and $\mathrm{BH} 1$ is responsible for the apoptotic activity of Bax. Genes Dev 21: 1937-1948.

Germain M, Mathai JP, Shore GC. 2002. BH-3-only BIK functions at the endoplasmic reticulum to stimulate cytochrome $c$ release from mitochondria. J Biol Chem 277: 18053-18060.

Grad JM, Zeng XR, Boise LH. 2000. Regulation of Bcl-xL: A little bit of this and a little bit of STAT. Curr Opin Oncol 12: $543-549$.

Griffiths GJ, Dubrez L, Morgan CP, Jones NA, Whitehouse J, Corfe BM, Dive C, Hickman JA. 1999. Cell damage-induced conformational changes of the pro-apoptotic protein Bak in vivo precede the onset of apoptosis. J Cell Biol 144: 903-914.

* Hardwick JM, Soane L. 2013. Multiple functions of BCL-2 family proteins. Cold Spring Harb Perspect Biol 5: a008722.

Hekman M, Albert S, Galmiche A, Rennefahrt UE, Fueller J, Fischer A, Puehringer D, Wiese S, Rapp UR. 2006. Reversible membrane interaction of $\mathrm{BAD}$ requires two $\mathrm{C}$ terminal lipid binding domains in conjunction with 143-3 protein binding. J Biol Chem 281: 17321-17336.

Hinds MG, Lackmann M, Skea GL, Harrison PJ, Huang DC, Day CL. 2003. The structure of Bcl-w reveals a role for the 
C-terminal residues in modulating biological activity. EMBO J 22: 1497-1507.

Hinds MG, Smits C, Fredericks-Short R, Risk JM, Bailey M, Huang DC, Day CL. 2007. Bim, Bad and Bmf: Intrinsically unstructured $\mathrm{BH} 3$-only proteins that undergo a localized conformational change upon binding to prosurvival Bcl-2 targets. Cell Death Differ 14: 128-136.

Hoppins S, Edlich F, Cleland MM, Banerjee S, McCaffery JM, Youle RJ, Nunnari J. 2011. The soluble form of Bax regulates mitochondrial fusion via MFN2 homotypic complexes. Mol Cell 41: 150-160.

Hsu YT, Youle RJ. 1997. Nonionic detergents induce dimerization among members of the Bcl-2 family. J Biol Chem 272: $13829-13834$.

Hsu YT, Wolter KG, Youle RJ. 1997. Cytosol-to-membrane redistribution of $\mathrm{Bax}$ and $\mathrm{Bcl}-\mathrm{X}(\mathrm{L})$ during apoptosis. Proc Natl Acad Sci 94: 3668-3672.

Hu X, Han Z, Wyche JH, Hendrickson EA. 2003. Helix 6 of tBid is necessary but not sufficient for mitochondrial binding activity. Apoptosis 8: 277-289.

Inohara N, Ding L, Chen S, Nunez G. 1997. harakiri, a novel regulator of cell death, encodes a protein that activates apoptosis and interacts selectively with survival-promoting proteins $\mathrm{Bcl}-2$ and $\mathrm{Bcl}-\mathrm{X}(\mathrm{L})$. EMBO J 16: 1686-1694.

Jabbour AM, Heraud JE, Daunt CP, Kaufmann T, Sandow J, O'Reilly LA, Callus BA, Lopez A, Strasser A, Vaux DL, et al. 2009. Puma indirectly activates Bax to cause apoptosis in the absence of Bid or Bim. Cell Death Differ 16: 555563.

Janiak F, Leber B, Andrews DW. 1994. Assembly of Bcl-2 into microsomal and outer mitochondrial membranes. J Biol Chem 269: 9842-9849.

Jeong SY, Gaume B, Lee YJ, Hsu YT, Ryu SW, Yoon SH, Youle RJ. 2004. Bcl- $\mathrm{x}(\mathrm{L})$ sequesters its C-terminal membrane anchor in soluble, cytosolic homodimers. EMBO J 23: 2146-2155.

Kalinec GM, Fernandez-Zapico ME, Urrutia R, EstebanCruciani N, Chen S, Kalinec F. 2005. Pivotal role of Harakiri in the induction and prevention of gentamicin-induced hearing loss. Proc Natl Acad Sci 102: 16019-16024.

Kamer I, Sarig R, Zaltsman Y, Niv H, Oberkovitz G, Regev L, Haimovich G, Lerenthal Y, Marcellus RC, Gross A. 2005. Proapoptotic BID is an ATM effector in the DNA-damage response. Cell 122: 593-603.

Karbowski M, Norris KL, Cleland MM, Jeong SY, Youle RJ. 2006. Role of Bax and Bak in mitochondrial morphogenesis. Nature 443: 658-662.

Kiefer MC, Brauer MJ, Powers VC, Wu JJ, Umansky SR, Tomei LD, Barr PJ. 1995. Modulation of apoptosis by the widely distributed $\mathrm{Bcl}-2$ homologue Bak. Nature 374: 736-739.

Kim PK, Annis MG, Dlugosz PJ, Leber B, Andrews DW. 2004. During apoptosis Bcl-2 changes membrane topology at both the endoplasmic reticulum and mitochondria. Mol Cell 14: 523-529.

Kim H, Rafiuddin-Shah M, Tu HC, Jeffers JR, Zambetti GP, Hsieh JJ, Cheng EH. 2006. Hierarchical regulation of mitochondrion-dependent apoptosis by BCL-2 subfamilies. Nat Cell Biol 8: 1348-1358.

Kim H, Tu HC, Ren D, Takeuchi O, Jeffers JR, Zambetti GP, Hsieh JJ, Cheng EH. 2009. Stepwise activation of BAX and BAK by tBID, BIM, and PUMA initiates mitochondrial apoptosis. Mol Cell 36: 487-499.

Kutuk O, Letai A. 2008. Regulation of Bcl-2 family proteins by posttranslational modifications. Curr Mol Med 8: $102-118$.

Kuwana T, Newmeyer DD. 2003. Bcl-2-family proteins and the role of mitochondria in apoptosis. Curr Opin Cell Biol 15: 691-699.

Kuwana T, Mackey MR, Perkins G, Ellisman MH, Latterich M, Schneiter R, Green DR, Newmeyer DD. 2002. Bid, Bax, and lipids cooperate to form supramolecular openings in the outer mitochondrial membrane. Cell 111: 331-342.

Kuwana T, Bouchier-Hayes L, Chipuk JE, Bonzon C, Sullivan BA, Green DR, Newmeyer DD. 2005. BH3 domains of $\mathrm{BH} 3$-only proteins differentially regulate Bax-mediated mitochondrial membrane permeabilization both directly and indirectly. Mol Cell 17: 525-535.

Kvansakul M, Yang H, Fairlie WD, Czabotar PE, Fischer SF, Perugini MA, Huang DC, Colman PM. 2008. Vaccinia virus anti-apoptotic F1 L is a novel Bcl-2-like domainswapped dimer that binds a highly selective subset of BH3-containing death ligands. Cell Death Differ 15: 1564-1571.

Landeta O, Landajuela A, Gil D, Taneva S, Diprimo C, Sot B, Valle M, Frolov V, Basanez G. 2011. Reconstitution of proapoptotic BAK function in liposomes reveals a dual role for mitochondrial lipids in the BAK-driven membrane permeabilization process. J Biol Chem 286: 82138230.

Leber B, Lin J, Andrews DW. 2007. Embedded together: The life and death consequences of interaction of the Bcl-2 family with membranes. Apoptosis 12: 897-911.

Leber B, Lin J, Andrews DW. 2010. Still embedded together binding to membranes regulates $\mathrm{Bcl}-2$ protein interactions. Oncogene 29: 5221-5230.

Lee EF, Czabotar PE, Yang H, Sleebs BE, Lessene G, Colman PM, Smith BJ, Fairlie WD. 2009. Conformational changes in $\mathrm{Bcl}-2$ pro-survival proteins determine their capacity to bind ligands. J Biol Chem 284: 30508-30517.

Letai A, Bassik MC, Walensky LD, Sorcinelli MD, Weiler S, Korsmeyer SJ. 2002. Distinct BH3 domains either sensitize or activate mitochondrial apoptosis, serving as prototype cancer therapeutics. Cancer Cell 2: 183-192.

Li H, Zhu H, Xu CJ, Yuan J. 1998. Cleavage of BID by caspase 8 mediates the mitochondrial damage in the Fas pathway of apoptosis. Cell 94: 491-501.

Liu X, Dai S, Zhu Y, Marrack P, Kappler JW. 2003. The structure of a Bcl-xL/Bim fragment complex: Implications for Bim function. Immunity 19: 341-352.

Llambi F, Moldoveanu T, Tait SW, Bouchier-Hayes L, Temirov J, McCormick LL, Dillon CP, Green DR. 2011. A unified model of mammalian BCL-2 protein family interactions at the mitochondria. Mol Cell 44: 517-531.

Lovell JF, Billen LP, Bindner S, Shamas-Din A, Fradin C, Leber B, Andrews DW. 2008. Membrane binding by tBid initiates an ordered series of events culminating in membrane permeabilization by Bax. Cell 135: $1074-$ 1084.

Lucken-Ardjomande S, Montessuit S, Martinou JC. 2008. Bax activation and stress-induced apoptosis delayed by 
the accumulation of cholesterol in mitochondrial membranes. Cell Death Differ 15: 484-493.

Luo X, Budihardjo I, Zou H, Slaughter C, Wang X. 1998. $\mathrm{Bid}, \mathrm{a} \mathrm{Bcl} 2$ interacting protein, mediates cytochrome $c$ release from mitochondria in response to activation of cell surface death receptors. Cell 94: 481-490.

Lutter M, Fang M, Luo X, Nishijima M, Xie X, Wang X. 2000. Cardiolipin provides specificity for targeting of tBid to mitochondria. Nat Cell Biol 2: 754-761.

* Mah LY, Ryan KM. 2012. Autophagy and cancer. Cold Spring Harb Perspect Biol 4: a008821.

McDonnell JM, Fushman D, Milliman CL, Korsmeyer SJ, Cowburn D. 1999. Solution structure of the proapoptotic molecule BID: A structural basis for apoptotic agonists and antagonists. Cell 96: 625-634.

Minn AJ, Kettlun CS, Liang H, Kelekar A, Vander Heiden MG, Chang BS, Fesik SW, Fill M, Thompson CB. 1999. Bcl-xL regulates apoptosis by heterodimerizationdependent and -independent mechanisms. EMBO J 18: 632-643.

Moldoveanu T, Liu Q, Tocilj A, Watson M, Shore G, Gehring K. 2006. The X-ray structure of a BAK homodimer reveals an inhibitory zinc binding site. Mol Cell 24: 677-688.

Monaco G, Decrock E, Akl H, Ponsaerts R, Vervliet T, Luyten T, De Maeyer M, Missiaen L, Distelhorst CW, De Smedt H, et al. 2011. Selective regulation of IP(3)receptor-mediated $\mathrm{Ca}^{2+}$ signaling and apoptosis by the $\mathrm{BH} 4$ domain of Bcl-2 versus Bcl-Xl. Cell Death Differ 19: 295-309.

Montessuit S, Somasekharan SP, Terrones O, Lucken-Ardjomande S, Herzig S, Schwarzenbacher R, Manstein DJ, Bossy-Wetzel E, Basanez G, Meda P, et al. 2010. Membrane remodeling induced by the dynamin-related protein Drp1 stimulates Bax oligomerization. Cell 142: 889-901.

Muchmore SW, Sattler M, Liang H, Meadows RP, Harlan JE, Yoon HS, Nettesheim D, Chang BS, Thompson CB, Wong SL, et al. 1996. X-ray and NMR structure of human Bcl-xL, an inhibitor of programmed cell death. Nature 381: 335-341.

Nakagawa T, Shimizu S, Watanabe T, Yamaguchi O, Otsu K, Yamagata H, Inohara H, Kubo T, Tsujimoto Y. 2005. Cyclophilin D-dependent mitochondrial permeability transition regulates some necrotic but not apoptotic cell death. Nature 434: 652-658.

Nakano K, Vousden KH. 2001. PUMA, a novel proapoptotic gene, is induced by p53. Mol Cell 7: 683-694.

Nechushtan A, Smith CL, Hsu YT, Youle RJ. 1999. Conformation of the Bax C-terminus regulates subcellular location and cell death. EMBO J 18: 2330-2341.

Nguyen M, Millar DG, Yong VW, Korsmeyer SJ, Shore GC. 1993. Targeting of Bcl-2 to the mitochondrial outer membrane by a $\mathrm{COOH}$-terminal signal anchor sequence. J Biol Chem 268: 25265-25268.

* Nixon RA, Yang D-S. 2012. Autophagy and neuronal cell death in neurological disorders. Cold Spring Harb Perspect Biol 4: a008839.

O'Connor L, Strasser A, O'Reilly LA, Hausmann G, Adams JM, Cory S, Huang DC. 1998. Bim: A novel member of the Bcl-2 family that promotes apoptosis. EMBO J 17: 384-395.

Oda E, Ohki R, Murasawa H, Nemoto J, Shibue T, Yamashita T, Tokino T, Taniguchi T, Tanaka N. 2000. Noxa, a BH3-only member of the Bcl-2 family and candidate mediator of p53-induced apoptosis. Science 288: 1053-1058.

Oh KJ, Singh P, Lee K, Foss K, Lee S, Park M, Aluvila S, Kim RS, Symersky J, Walters DE. 2010. Conformational changes in BAK, a pore-forming proapoptotic $\mathrm{Bcl}-2 \mathrm{fam}$ ily member, upon membrane insertion and direct evidence for the existence of $\mathrm{BH} 3-\mathrm{BH} 3$ contact interface in BAK homo-oligomers. J Biol Chem 285: 28924-28937.

Oltvai ZN, Milliman CL, Korsmeyer SJ. 1993. Bcl-2 heterodimerizes in vivo with a conserved homolog, Bax, that accelerates programmed cell death. Cell 74: 609-619.

Pavlov EV, Priault M, Pietkiewicz D, Cheng EH, Antonsson B, Manon S, Korsmeyer SJ, Mannella CA, Kinnally KW. 2001. A novel, high conductance channel of mitochondria linked to apoptosis in mammalian cells and Bax expression in yeast. J Cell Biol 155: 725-731.

Peyerl FW, Dai S, Murphy GA, Crawford F, White J, Marrack P, Kappler JW. 2007. Elucidation of some Bax conformational changes through crystallization of an antibody-peptide complex. Cell Death Differ 14: 447-452.

Ploner C, Kofler R, Villunger A. 2008. Noxa: At the tip of the balance between life and death. Oncogene 27(Suppl 1): S84-S92.

Puthalakath H, Villunger A, O’Reilly LA, Beaumont JG, Coultas L, Cheney RE, Huang DC, Strasser A. 2001. Bmf: A proapoptotic BH3-only protein regulated by interaction with the myosin $\mathrm{V}$ actin motor complex, activated by anoikis. Science 293: 1829-1832.

Qian S, Wang W, Yang L, Huang HW. 2008. Structure of transmembrane pore induced by Bax-derived peptide: evidence for lipidic pores. Proc Natl Acad Sci 105: 17379-17383.

Rong YP, Bultynck G, Aromolaran AS, Zhong F, Parys JB, De Smedt H, Mignery GA, Roderick HL, Bootman MD, Distelhorst CW. 2009. The BH4 domain of Bcl-2 inhibits ER calcium release and apoptosis by binding the regulatory and coupling domain of the IP3 receptor. Proc Natl Acad Sci 106: 14397-14402.

Sattler M, Liang H, Nettesheim D, Meadows RP, Harlan JE, Eberstadt M, Yoon HS, Shuker SB, Chang BS, Minn AJ, et al. 1997. Structure of Bcl-xL-Bak peptide complex: Recognition between regulators of apoptosis. Science 275: 983-986.

Schafer B, Quispe J, Choudhary V, Chipuk JE, Ajero TG, Du H, Schneiter R, Kuwana T. 2009. Mitochondrial outer membrane proteins assist Bid in Bax-mediated lipidic pore formation. Mol Biol Cell 20: 2276-2285.

Schwarz M, Andrade-Navarro MA, Gross A. 2007. Mitochondrial carriers and pores: Key regulators of the mitochondrial apoptotic program? Apoptosis 12: 869-876.

Schwickart M, Huang X, Lill JR, Liu J, Ferrando R, French DM, Maecker H, O'Rourke K, Bazan F, Eastham-Anderson J, et al. 2010. Deubiquitinase USP9X stabilizes MCL1 and promotes tumour cell survival. Nature 463: 103-107.

Seo YW, Shin JN, Ko KH, Cha JH, Park JY, Lee BR, Yun CW, Kim YM, Seol DW, Kim DW, et al. 2003. The molecular 
mechanism of Noxa-induced mitochondrial dysfunction in p53-mediated cell death. J Biol Chem 278: 4829248299.

Setoguchi K, Otera H, Mihara K. 2006. Cytosolic factor- and TOM-independent import of C-tail-anchored mitochondrial outer membrane proteins. $E M B O J$ 25: 5635-5647.

Shamas-Din A, Brahmbhatt H, Leber B, Andrews DW. 2011. BH3-only proteins: Orchestrators of apoptosis. Biochim Biophys Acta 1813: 508-520.

Shimizu S, Narita M, Tsujimoto Y. 1999. Bcl-2 family proteins regulate the release of apoptogenic cytochrome $c$ by the mitochondrial channel VDAC. Nature 399: 483-487.

Simmons MJ, Fan G, Zong WX, Degenhardt K, White E, Gelinas C. 2008. Bfl-1/A1 functions, similar to Mcl-1, as a selective tBid and Bak antagonist. Oncogene 27: $1421-1428$.

Sinha S, Levine B. 2008. The autophagy effector Beclin 1: A novel BH3-only protein. Oncogene 27 (Suppl 1): S137S148.

Spencer SL, Sorger PK. 2011. Measuring and modeling apoptosis in single cells. Cell 144: 926-939.

Stewart ML, Fire E, Keating AE, Walensky LD. 2010. The MCL-1 BH3 helix is an exclusive MCL-1 inhibitor and apoptosis sensitizer. Nat Chem Biol 6: 595-601.

Suzuki M, Youle RJ, Tjandra N. 2000. Structure of Bax: Coregulation of dimer formation and intracellular localization. Cell 103: 645-654.

Tsujimoto Y, Shimizu S. 2007. Role of the mitochondrial membrane permeability transition in cell death. Apoptosis 12: 835-840.

Wang K, Yin XM, Chao DT, Milliman CL, Korsmeyer SJ. 1996. BID: A novel BH3 domain-only death agonist. Genes Dev 10: 2859-2869.

Weber A, Paschen SA, Heger K, Wilfling F, Frankenberg T, Bauerschmitt H, Seiffert BM, Kirschnek S, Wagner H, Hacker G. 2007. BimS-induced apoptosis requires mitochondrial localization but not interaction with antiapoptotic Bcl-2 proteins. J Cell Biol 177: 625-636.

Wei MC, Zong WX, Cheng EH, Lindsten T, Panoutsakopoulou V, Ross AJ, Roth KA, MacGregor GR, Thompson CB, Korsmeyer SJ. 2001. Proapoptotic BAX and BAK: A requisite gateway to mitochondrial dysfunction and death. Science 292: 727-730.

Willimott S, Wagner SD. 2010. Post-transcriptional and post-translational regulation of Bcl2. Biochem Soc Trans 38: $1571-1575$.

Willis SN, Chen L, Dewson G, Wei A, Naik E, Fletcher JI, Adams JM, Huang DC. 2005. Proapoptotic Bak is seques-
Mechanisms of Action of Bcl-2 Family Members

tered by Mcl-1 and Bcl-xL, but not Bcl-2, until displaced by BH3-only proteins. Genes Dev 19: 1294-1305.

Wilson-Annan J, O’Reilly LA, Crawford SA, Hausmann G, Beaumont JG, Parma LP, Chen L, Lackmann M, Lithgow T, Hinds MG, et al. 2003. Proapoptotic BH3only proteins trigger membrane integration of prosurvival Bcl-w and neutralize its activity. J Cell Biol 162: 877-887.

Wolter KG, Hsu YT, Smith CL, Nechushtan A, Xi XG, Youle RJ. 1997. Movement of Bax from the cytosol to mitochondria during apoptosis. J Cell Biol 139: 1281 1292.

Yang L, Harroun TA, Weiss TM, Ding L, Huang HW. 2001. Barrel-stave model or toroidal model? A case study on melittin pores. Biophys J 81: 1475-1485.

Yeretssian G, Correa RG, Doiron K, Fitzgerald P, Dillon CP, Green DR, Reed JC, Saleh M. 2011. Non-apoptotic role of BID in inflammation and innate immunity. Nature 474: 96-99.

Yethon JA, Epand RF, Leber B, Epand RM, Andrews DW. 2003. Interaction with a membrane surface triggers a reversible conformational change in bax normally associated with induction of apoptosis. J Biol Chem 278: 48935-48941.

Yi CH, Pan H, Seebacher J, Jang IH, Hyberts SG, Heffron GJ, Vander Heiden MG, Yang R, Li F, Locasale JW, et al. 2011. Metabolic regulation of protein $N$ - $\alpha$-acetylation by BclxL promotes cell survival. Cell 146: 607-620.

Zaltsman Y, Shachnai L, Yivgi-Ohana N, Schwarz M, Maryanovich M, Houtkooper RH, Vaz FM, De Leonardis F Fiermonte G, Palmieri F, et al. 2010. MTCH2/MIMP is a major facilitator of tBID recruitment to mitochondria. Nat Cell Biol 12: 553-562.

Zha J, Harada H, Osipov K, Jockel J, Waksman G, Korsmeyer SJ. 1997. BH3 domain of BAD is required for heterodimerization with BCL-XL and pro-apoptotic activity. J Biol Chem 272: 24101-24104.

Zhang Z, Zhu W, Lapolla SM, Miao Y, Shao Y, Falcone M, Boreham D, McFarlane N, Ding J, Johnson AE, et al. 2010. Bax forms an oligomer via separate, yet interdependent, surfaces. J Biol Chem 285: 17614-17627.

Zhong Q, Gao W, Du F, Wang X. 2005. Mule/ARF-BP1, a BH3-only E3 ubiquitin ligase, catalyzes the polyubiquitination of Mcl-1 and regulates apoptosis. Cell 121: 1085-1095.

Zinkel SS, Hurov KE, Ong C, Abtahi FM, Gross A, Korsmeyer SJ. 2005. A role for proapoptotic BID in the DNA-damage response. Cell 122: 579-591. 


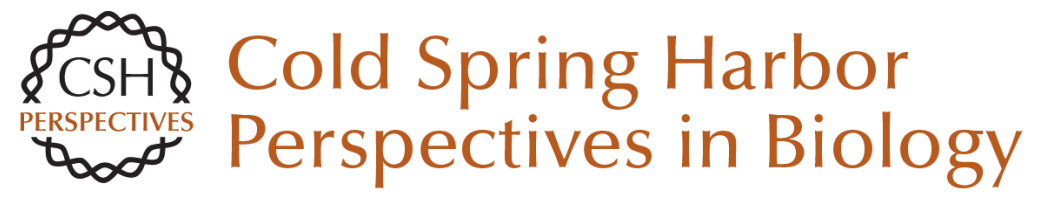

\section{Mechanisms of Action of Bcl-2 Family Proteins}

Aisha Shamas-Din, Justin Kale, Brian Leber and David W. Andrews

Cold Spring Harb Perspect Biol 2013; doi: 10.1101/cshperspect.a008714

Subject Collection Cell Survival and Cell Death

Programmed Cell Death in the Evolutionary Race against Bacterial Virulence Factors

Carolyn A. Lacey and Edward A. Miao

The Evolutionary Origins of Programmed Cell

Death Signaling

Kay Hofmann

Regulation of Cell Death and Immunity by XIAP Philipp J. Jost and Domagoj Vucic

Dysregulation of Cell Death in Human Chronic Inflammation

Yue Li, Christoph Klein and Daniel Kotlarz

Cell Death in Plant Immunity

Eugenia Pitsili, Ujjal J. Phukan and Nuria S. Coll

Recent Insights on Inflammasomes, Gasdermin Pores, and Pyroptosis

Nathalia M. de Vasconcelos and Mohamed Lamkanfi

Phagocyte Responses to Cell Death in Flies Andrew J. Davidson and Will Wood

Mechanism and Regulation of

Gasdermin-Mediated Cell Death

Shiyu Xia, Louis Robert Hollingsworth IV and Hao Wu
Cell Death and Neurodegeneration Benjamin J. Andreone, Martin Larhammar and Joseph W. Lewcock

Death Receptors and Their Ligands in Inflammatory Disease and Cancer Alessandro Annibaldi and Henning Walczak

The Killer Pseudokinase Mixed Lineage Kinase Domain-Like Protein (MLKL) James M. Murphy

Neutrophil Extracellular Traps in Host Defense Sabrina Sofia Burgener and Kate Schroder

Cell-Cycle Cross Talk with Caspases and Their Substrates Patrick Connolly, Irmina Garcia-Carpio and Andreas Villunger

Cracking the Cell Death Code Carla V. Rothlin and Sourav Ghosh

BAX, BAK, and BOK: A Coming of Age for the BCL-2 Family Effector Proteins

Tudor Moldoveanu and Peter E. Czabotar

Multitasking Kinase RIPK1 Regulates Cell Death and Inflammation

Kim Newton

For additional articles in this collection, see http://cshperspectives.cshlp.org/cgi/collection/

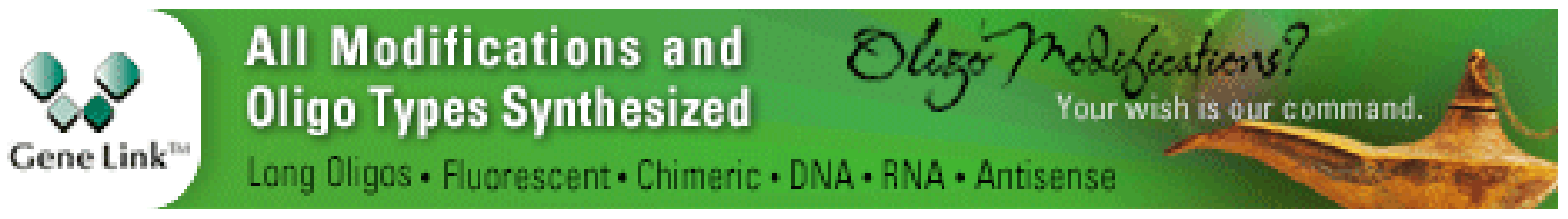

Copyright @ 2013 Cold Spring Harbor Laboratory Press; all rights reserved 
For additional articles in this collection, see http://cshperspectives.cshlp.org/cgi/collection/

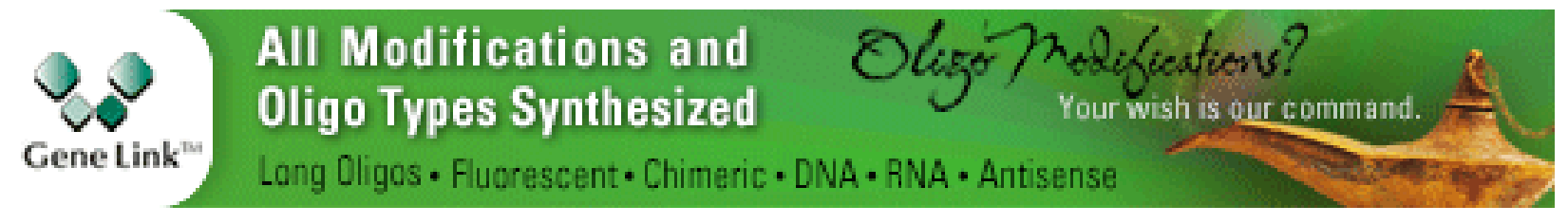

Copyright @ 2013 Cold Spring Harbor Laboratory Press; all rights reserved 